\title{
PRIVATE EQUITY AND EMPLOYMENT
}

By

\author{
Steven J. Davis * \\ University of Chicago
}

John Haltiwanger*
University of Maryland

Ron Jarmin *

U.S. Bureau of the Census

Josh Lerner *

Harvard University

and

Javier Miranda *

U.S. Bureau of the Census

CES 08-07R October, 2011

This paper is a revised version of "Private Equity and Employment" (CES-WP-08-07) from March 2008. A copy of the original paper is available upon request.

The research program of the Center for Economic Studies (CES) produces a wide range of economic analyses to improve the statistical programs of the U.S. Census Bureau. Many of these analyses take the form of CES research papers. The papers have not undergone the review accorded Census Bureau publications and no endorsement should be inferred. Any opinions and conclusions expressed herein are those of the author(s) and do not necessarily represent the views of the U.S. Census Bureau. All results have been reviewed to ensure that no confidential information is disclosed. Republication in whole or part must be cleared with the authors.

To obtain information about the series, see www.census.gov/ces or contact Cheryl Grim, Editor, Discussion Papers, U.S. Census Bureau, Center for Economic Studies 2K130B, 4600 Silver Hill Road, Washington, DC 20233, CES.Papers.List@census.gov. 


\begin{abstract}
Private equity critics claim that leveraged buyouts bring huge job losses. To investigate this claim, we construct and analyze a new dataset that covers U.S. private equity transactions from 1980 to 2005. We track 3,200 target firms and their 150,000 establishments before and after acquisition, comparing outcomes to controls similar in terms of industry, size, age, and prior growth. Relative to controls, employment at target establishments declines 3 percent over two years post buyout and 6 percent over five years. The job losses are concentrated among public-to-private buyouts, and transactions involving firms in the service and retail sectors. But target firms also create more new jobs at new establishments, and they acquire and divest establishments more rapidly. When we consider these additional adjustment margins, net relative job losses at target firms are less than 1 percent of initial employment. In contrast, the sum of gross job creation and destruction at target firms exceeds that of controls by 13 percent of employment over two years. In short, private equity buyouts catalyze the creative destruction process in the labor market, with only a modest net impact on employment. The creative destruction response mainly involves a more rapid reallocation of jobs across establishments within target firms.
\end{abstract}

JEL Codes: D22, G34, L25, M54

Keywords: Private Equity, Buyouts, Leverage, Job Loss, Job Creation, Employment Dynamics

* University of Chicago; University of Maryland; US Census Bureau; Harvard University; and US Census Bureau. Davis, Haltiwanger, and Lerner are research associates with the National Bureau of Economic Research. We thank Chris Allen, Ronald Davis, Kyle Handley, and Sarah Woolverton for research assistance with this project and Per Stromberg for data on the classification of private equity transactions. Francesca Cornelli, Per Stromberg, a number of practitioners, and participants at the American Economic Association meetings, the NBER "New World of Private Equity" conference, the AEI Conference on "The History, Impact and Future of Private Equity," and various university conferences and seminars provided many helpful comments. The World Economic Forum, the Kauffman Foundation, Harvard Business School's Division of Research, and the Global Markets Initiative at the University of Chicago Booth School of Business provided generous financial support for this research. One of the authors has advised institutional investors in private equity funds, private equity groups, and governments designing policies relevant to private equity. Any opinions and conclusions expressed herein are those of the authors and do not necessarily represent the views of the U.S. Census Bureau. All results have been reviewed to ensure that no confidential information is disclosed. All errors and omissions are our own. 


\section{Introduction}

The employment impact of leveraged buyouts by private equity firms arouses intense concern and strongly held views. For instance, former Danish Prime Minister Poul Rasmussen architect of the European Commission's recently enacted Alternative Investment Fund Managers Directive - contends that “'leveraged buy-outs’ leave the company saddled with debt and interest payments, its workers are laid off, and its assets are sold, ... benefiting neither workers nor the real economy.” The Service Employees International Union, prominent critic of private equity on both sides of the Atlantic, offers this assessment: “Typically it's easier to decrease costs quickly by cutting heads, which is why buyouts have typically been accompanied by layoffs.”1 Responding to similar contentions, several industry-sponsored studies claim positive employment effects of private equity. Examples include European Venture Capital Association (2005), British Venture Capital Association (2006), A.T. Kearney (2007), Taylor and Bryant (2007), and Shapiro and Pham (2008).

Efforts to bring data to the issue are highly welcome, but these studies have serious limitations. First, they rely on surveys with incomplete and perhaps selective responses, raising doubts as to whether the data accurately reflect the experiences of employers acquired by private equity groups. Second, the underlying data offer little scope to control for employment changes at comparable firms. When a firm backed by private equity sheds $5 \%$ of employment, the interpretation depends greatly on whether comparable firms grow by $3 \%$ or shrink by $10 \%$. Third, these studies do not distinguish cleanly between employment changes at firms backed by venture capital and firms backed by other forms of private equity. Both are interesting, but the controversy involves buyouts and other later-stage private equity transactions, not venture

\footnotetext{
${ }^{1}$ See Rasmussen (2008) and remarks attributed to John Adler in Grace Wong, "Private Equity and the Jobs Cut Myth”, CNNMoney.com, 2 May 2007 at http://money.cnn.com/2007/05/02/markets/pe_jobs/index.htm (accessed August 25, 2011).
} 
capital. Fourth, these studies face major difficulties in measuring organic job growth because the underlying data sources do not contain establishment-level observations. As a result, it is difficult to disentangle organic growth from the acquisition and sale of particular facilities and operating units. Fifth, the lack of establishment-level data also precludes a breakdown of firmlevel employment changes into job creation and job destruction components, i.e., gains and losses at the establishment level. As we show, private equity transactions have different effects on these two margins of employment change. ${ }^{2}$

In this study, we construct and analyse a dataset that overcomes these limitations and, at the same time, encompasses a much larger set of employers and private equity transactions. We rely on the Longitudinal Business Database (LBD) at the U.S. Census Bureau to follow employment in private equity-backed companies in the United States. Using the LBD, we track employment before and after private equity transactions at the level of firms and establishments - i.e., specific factories, offices, retail outlets and other distinct physical locations where business takes place. The LBD covers the entire nonfarm private sector and includes annual data on employment for about 5 million firms and 6 million establishments. In addition to its other strengths, the establishment-level information in the LBD enables us to explore important aspects of within-firm restructuring activity in the wake of private equity events.

We combine the LBD with data from CapitalIQ and other sources to identify and characterize private equity transactions. The resulting matched sample contains about 3,200 U.S. firms acquired in private equity transactions from 1980 to 2005 ("target firms”) and 150,000 U.S. establishments operated by these firms as of the transaction ("target establishments"). To construct firm-level controls, we match each target to other firms in the transaction year that are

\footnotetext{
2 See Service Employees International Union (2007) and Hall (2007) for other critiques. We discuss the broader academic literature on the economic effects of private equity in Section 2. Few academic studies of private equity focus on employment outcomes, and the main exceptions consider data for France and the United Kingdom.
} 
comparable in terms of industry, age, size, and single/multi-establishment status. We then follow targets and matched controls over time. We take a similar approach to controls for target establishments. In our econometric analysis of employment dynamics, we also control for prebuyout growth history.

To clarify the scope of our study, we consider later-stage changes in ownership and control executed and partly financed by private equity firms. In these transactions, the (lead) private equity firm acquires a controlling stake in the target firm and retains a significant oversight role until it "exits" by selling its stake. The transaction typically involves a shift toward greater leverage in the capital structure of the target firm and, sometimes, a change in its management. We exclude management-led buyouts that do not involve a private equity firm. We also exclude startup firms backed by venture capitalists.

There are three main elements in our analysis of employment outcomes associated with private equity transactions. First, we track target establishments for five years before and after the transaction, irrespective of whether the target firm owns and operates these establishments throughout the entire time window. We compare the paths of employment, job creation, and job destruction at target establishments to the paths at control establishments. By following individual production units over time, this element of our analysis overcomes key shortcomings in previous studies of private equity buyouts. Those studies are not able to describe what happens to the particular establishments and workers initially touched by private equity acquisitions. Second, we undertake a firm-level analysis to encompass job creation at "greenfield" establishments opened after the private equity transaction. We identify and quantify greenfield job creation by target firms backed by private equity and compare with greenfield job creation by control firms. Our firm-level analysis also captures employment changes associated with acquisitions and divestitures. Third, we draw on the first two elements of our analysis to 
quantify the effects of private equity transactions on the reallocation of jobs across establishments within and between firms. Taken together, the various elements of our analysis yield a much fuller and richer picture of the relationship between private equity transactions and employment outcomes.

Our establishment-level analysis yields three main findings: First, employment shrinks more rapidly, on average, at target establishments than at controls after private equity transactions. The average cumulative difference in favor of controls is about $3 \%$ of initial employment over two years and 6\% over five years. Second, the larger post-transaction employment declines at target establishments entirely reflect higher rates of job destruction at shrinking and exiting establishments. In fact, the post-transaction creation of new jobs at expanding establishments is greater for targets than controls. Third, mean employment growth rates are similar for target and control establishments in the two years before buyout, and targets grow more rapidly in the transaction year.

The establishment-level analysis does not fully answer the question of how employment evolves in the wake of private equity transactions. Most important, it misses job creation at newly opened establishments, whether by target or control firms. To capture this aspect of job creation, we move to a firm-level analysis and identify new establishments opened after the private equity transaction. The combination of firm and establishment data in the LBD is what enables us to isolate and quantify greenfield job creation. For this part of our analysis, we shorten the time window to two years post transaction. Lengthening the window involves a greater incidence and complexity of ownership changes, threatening the integrity of our firmlevel longitudinal linkages or forcing us to rely on a selected sample.

Target firms engage in more greenfield job creation than control firms, with a cumulative two-year difference amounting to almost $2 \%$ of transaction-year employment. That is, greater 
greenfield job creation partly offsets the relative employment drop at target establishments in the wake of private equity transactions. Our firm-level analysis also yields another interesting result: Private equity targets engage in more acquisitions and more divestitures than controls. Over the first two years post buyout, the employment-weighted acquisition rate is almost 6 percentage points higher at target firms, and the divestiture rate is almost 3 percentage points higher. Summing over job creation and destruction at continuing establishments, job losses at establishments that shut down, job gains at greenfield establishments, and the contributions of acquisitions and divestitures, employment shrinks by less than $1 \%$ at target firms relative to controls in the first two years after private equity buyouts.

We uncover a much larger response in the pace of job reallocation. Specifically, over the first two years after the transaction, establishment-level job gains and losses at target firms exceed gains and losses at controls by $13 \%$ of initial employment. This extra job creation and destruction activity amounts to more than $30 \%$ of baseline job reallocation rates at control firms. A more rapid pace of organic job creation and destruction accounts for $43 \%$ of the extra reallocation activity at target firms, and a more rapid pace of acquisitions and divestitures accounts for the rest. These results indicate that private equity buyouts catalyze the creative destruction process, at least as measured by job creation and destruction and by the transfer of production units between firms.

We also document large outcome differences by type of private equity transaction and by industry. The most visible transactions involve publicly traded firms that come under private equity control. These public-to-private cases account for a small share of transactions but are typically larger than other deals, and they attract the lion's share of media attention. As it turns out, target-firm employment losses are much greater in public-to-private transactions than other private equity buyouts. Relative to controls, employment shrinks by $10 \%$ of initial employment 
in the first two years after private equity buyouts of publicly traded firms. There are also large differences by industry. In the manufacturing sector, which accounts for about a quarter of U.S. private equity transactions, post-buyout growth at target establishments is only slightly slower than at controls. In contrast, Services and especially Retail Trade exhibit much larger employment declines at target establishments in the wake of private equity buyouts.

The next section briefly reviews related research. Section 3 describes the construction of the datasets for our analysis, and Section 4 motivates and explains our empirical methods. Sections 5 and 6 present our main establishment-level and firm-level analyses. Section 7 draws out the implications for job reallocation and the role of private equity in the creative destruction process. Section 8 highlights important outcome differences by industry and type of transaction, and Section 9 offers concluding remarks.

\section{2. $\quad$ Related Work}

Economists hold a longstanding interest in how ownership changes affect productivity and employment. Examples include Lichtenberg and Siegel (1987), Long and Ravenscraft (1993), McGuckin and Nguyen (2001), and Harris, Siegel and Wright (2005). One ownership change that attracts particular attention is the acquisition of firms by professional private equity investors. Jensen (1989) and Shleifer and Summers (1988), among others, discuss the economic

effects of private equity transactions based largely on case study evidence. Kaplan and Strömberg (2009) provide a useful overview of research on the economic effects of private equity.

Few previous studies focus on the employment effects of private equity transactions, and the exceptions typically rely on small samples dictated by data availability. Kaplan (1989) considers 76 public-to-private leveraged buyouts (LBOs) during the 1980s. He finds that the median firm lost $12 \%$ of employment on an industry-adjusted basis from the end of the fiscal 
year prior to the private equity transaction to the end of the fiscal year after the transaction. After dropping target firms with asset sales or purchases that exceed 10\% of total value, the adjusted employment decline is $6.2 \%$ for the remaining 24 firms. Muscarella and Vetsuypens (1990) consider 72 firms that completed an initial public offering (IPO) after an LBO between 1983 and 1987. For the 26 firms they can track, employment declines by an average of $0.6 \%$ between the LBO and the IPO. This outcome represents less employment growth than $92 \%$ of the publicly traded firms in Compustat.

In work close in spirit to our study, Lichtenberg and Siegel (1990) use U.S. Census Bureau data to examine changes in employment at the manufacturing plants of 131 firms undergoing buyouts between 1981 and 1986. On an industry-adjusted basis, employment falls by $1.2 \%$ per year after buyout, as compared to a $1.9 \%$ annual rate of decline beforehand. Declines are larger for non-production workers than blue-collar workers. Wright, Thompson and Robbie (1992) and Amess and Wright (2007) similarly find that buyouts in the UK lead to modest employment declines. These studies follow overall employment at a set of firms, and contrast it with aggregate employment at matching firms. ${ }^{3}$ Boucly, Sraer and Thesmar (2009) find that employment grows much more rapidly at target firms than at controls in the wake of French private equity transactions. They attribute this result to an important role for private equity in relaxing financing constraints for target firms in France.

These studies share certain weaknesses. First, they focus on the company-wide employment of firms backed by private equity. Thus, the sale of a division or other business unit is typically counted as an employment loss, even if the sold business unit continues with the same number of employees under new ownership. Likewise, the acquisition of a division or other

\footnotetext{
${ }^{3}$ The samples in these UK studies include management-led deals (management buyouts), which need not involve a financial sponsor that acquires a controlling stake in the target firm. Management-led deals potentially differ substantially from the traditional private equity transactions that we consider.
} 
business unit is counted as an employment gain, even if there is no employment change at the business unit itself. Several studies attempt to address this issue by dropping buyouts that involve substantial asset sales, but this sample restriction may greatly influence the results, given the extent of "asset shuffling” by firms backed by private equity.

Second, previous U.S. studies consider a modest number of deals in the 1980s. The private equity industry is now much larger. Using inflation-adjusted dollars, fundraising by U.S. private equity groups rose 36 -fold from 1985 to 1998 and more than 100 -fold by $2006 .{ }^{4}$ The tremendous growth in private equity activity allows us to examine a much larger set of deals. Moreover, the nature of private equity activity has also changed over time - competition for attractive deals has intensified, and many private equity firms now have a strong operational orientation, as opposed to the financial engineering approach that characterized many groups during the 1980s.

Third, previous U.S. studies of private equity deals rely on highly selected samples, and most studies treat the firm as the unit of analysis. The selected nature of the sample is a potentially important source of bias in the findings. The handful of previous studies that treat establishments as the unit of observation are typically restricted to the manufacturing sector, and even then face limitations in their ability to track establishment or firm closings. It is also desirable to look beyond the public-to-private transactions that dominate earlier samples, but which account for a minority of transactions.

Our study overcomes these weaknesses, as we have explained. In addition, we exploit the establishment-level aspect of our data to examine job creation and job destruction outcomes, as well as net employment changes. In this regard, we are motivated in part by previous work that documents a rapid pace of establishment-level job creation and destruction. Davis and

\footnotetext{
${ }^{4}$ Based on Thomson Reuters VentureXpert, http://www.venturexpert.com (accessed August 20, 2011).
} 
Haltiwanger (1999) review work in this area. Earlier empirical work also shows that the reallocation of jobs and workers across establishments plays a major role in medium-term productivity gains. Many important theoretical models also feature distinct roles for the creation and destruction margins of employment adjustment. Caballero (2007) provides an insightful, detailed analysis and extensive references to the relevant literature.

\section{Constructing the Analysis Samples}

Our analysis requires a comprehensive database of private equity transactions and the matching of target firms to firm-level and establishment-level records in the LBD. This section describes the data construction process and the resulting samples.

\section{A. Identifying Private Equity Transactions}

CapitalIQ has specialized in tracking private equity deals on a worldwide basis since 1999 and, through extensive research, has backfilled transactions prior to $1999 .{ }^{5}$ We consider all recorded transactions in CapitalIQ that closed between January 1980 and December 2005. We then impose two sample restrictions. First, we restrict attention to transactions that entail some use of leverage. Many transactions that do not involve leverage are venture capital investments rather than private equity investments in mature firms. To keep the focus on private equity, we delete transactions not classified by CapitalIQ as "going private," "leveraged buyout," “management buyout," "platform,” or a similar term. This approach excludes "growth buyouts” and "expansion capital" transactions that involve the purchase of a minority stake using little or no leverage. These transactions do not fit the classic profile of leveraged buyouts, although they may share other characteristics of private equity transactions. Second, the CapitalIQ database includes a number of transactions that do not involve a financial sponsor, i.e., a private equity

\footnotetext{
${ }^{5}$ Most data services tracking private equity transactions were not established until the late 1990s. The most comprehensive exception, SDC VentureXpert, mainly focused on capturing venture capital transactions until the mid-1990s. See Stromberg (2007) for a discussion of the completeness of the CapitalIQ database.
} 
firm. We delete these deals as well. While transactions in which a management team takes a firm private using its own resources are interesting, they are not the focus of our study or the recent controversies surrounding private equity activity.

After restricting the sample in these two ways, the resulting database contains about 11,000 transactions worldwide. Dropping transactions that involve firms with foreign headquarters leaves about 5,000 U.S. target firms acquired in private equity transactions between 1980 and 2005. (We do not consider U.S. establishments operated by foreign targets.) To fill out our information about private equity transactions and target firms, we supplement the data drawn from CapitalIQ with data from Dealogic, Thomson Reuters SDC, VentureXpert databases, and news stories. Dealogic, in particular, often contains greater detail about transaction characteristics. Other useful information in the supplementary sources includes alternative names associated with target firms and their later acquisitions and sales.

\section{B. $\quad$ Matching to LBD Records}

The LBD derives from the Census Bureau's Business Register, which contains annual data on U.S. businesses with paid employees. The LBD covers the entire nonfarm private sector from 1976 to 2005. In recent years, it contains over 6 million establishment records and almost 5 million firm records per year. The Business Register and the LBD draw on administrative records and survey sources for data on firms and their establishments. Core data items include employment, payroll, four-digit Standard Industrial Classification (SIC) or six-digit North American Industrial Classification (NAICS), employer identification numbers, business names, and information about location. ${ }^{6}$ Identifiers in the LBD files enable us to compute growth rate measures for establishments and firms and to track their entry and exit and ownership changes.

\footnotetext{
${ }^{6}$ Sales data in the Business Register are available annually from 1994 and once every five years in earlier years.
} 
Firms in the LBD are defined based on operational control, and all establishments majority owned by a parent firm are included in the parent's activity measures.

To merge data on private equity transactions into the LBD, we match names and addresses of private equity portfolio firms (i.e., target firms) to LBD name and address records. To cope with timing differences between datasets, we search over a three-year window in the LBD centered on the transaction year for each target firm. We adopt a conservative approach to matching that requires either an exact match on name or address or an approximate match on both name and address according to probability-based matching algorithms. Our procedures match about $65 \%$ of target firms to the LBD, $70 \%$ on a value-weighted basis, yielding about 3,200 matched targets firms. Once matched, firm-establishment links in the LBD serve to identify all establishments owned by target firms as of the private equity transaction. Matched target firms operate about 150,000 U.S. establishments as of the transaction year. LBD longitudinal links allows us to follow individual firms and establishments over time. As discussed below, tracking firms is more challenging than tracking establishments, which influences the design of our firm-level analysis sample.

Given our interest in employment dynamics, the relationship of the LBD employment measure to the timing of private equity transactions requires careful treatment. The LBD reports total employment in the payroll period containing the week of March 12th. Accordingly, for private equity transactions that close before October 1, LBD employment in March of the same calendar year serves as our contemporaneous employment measure. We assign transactions that close on or after October 1 in year $t$ to year $t+1$ for purposes of our analysis, treating the LBD employment value in March of $t+1$ as the contemporaneous measure. October is the natural cutoff because it lies midway between March-to-March employment changes in the LBD. 
Figure 1 shows the number of U.S. target firm acquisitions by year and the number matched to the LBD. It is apparent that the number of private equity transactions grew rapidly beginning in the mid-1990s. Table 1 shows the enterprise value (debt plus equity, as valued at the time of the transaction) of all private equity targets and the matched targets by sub-periods (we group years together in Table 1 to avoid disclosing individual firm data given the skewed distribution of values). The enterprise value of private equity acquisitions is very large in the later years, reaching 420 billion in the 2000-2005 period. Figure 2 displays employment data for our matched target firms. For example, target firms acquired in 2005 and identified in the LBD account for $0.83 \%$ of total nonfarm business employment in 2005 . Given the extent of unmatched targets, the full set of firms that came under private equity control in 2005 accounts for well over one percent of private sector employment. Based on our data, it is reasonable to infer that more than 7 percent of private sector employment came under private equity control at some point in the ten-year period from 1998 to $2007 .^{7}$

\section{Target Firms and Establishments in the Analysis Samples}

Our study considers three related samples. For descriptive statistics on the number and volume of private equity transactions and their distribution by industry and firm characteristics, we consider all matched targets through 2005. For our establishment-level analysis sample, we consider private equity transactions from 1980 to 2000. This sample allows us to track target establishments for five years before and after the buyout year. For our firm-level analysis sample, we consider transactions from 1980 to 2003, so that we can track firm-level outcomes for two years post-transaction. Table 2 reports summary statistics on matched targets for our three analysis samples.

\footnotetext{
${ }^{7}$ We arrive at this inference by summing the employment percentages of matched targets from 1998 to 2005 , dividing the sum by 0.7 to account for unmatched targets, and making the assumption (supported by other data sources) that private equity activity continued at record levels in 2006 and the first half of 2007.
} 


\section{Empirical Methods}

This section describes key methodological choices in our empirical study. The first relates to the unit of analysis. Section 5 considers establishments owned by a target firm in the year of a private equity transaction. We track these units over time, irrespective of their ownership in earlier or later years. For example, if the target firm goes public or sells an establishment, we continue to track that establishment and associate it with the transaction event. Section 6 takes a different approach, treating the firm as the unit of analysis. The firm-level approach allows us to capture greenfield job creation and the acquisition and sale of establishments after the private equity transaction.

The second key choice relates to controls. We need suitable controls because the distribution of private equity transactions across industries and by firm and establishment characteristics is not random. For example, practitioner accounts often suggest a concentration of transactions in industries undergoing significant restructurings due to regulatory action, foreign competition, or technological change. Target firms in our data are disproportionately concentrated in manufacturing, information services, and accommodation and food services, as seen in Figures 3A and 3B. Target firms are also larger and older than the average firm, as shown in Figure 4. The literature on firm dynamics concludes that growth and volatility vary systematically with firm size and age. See, for example, Caves (1998), Davis et al. (2007), and Haltiwanger, Jarmin and Miranda (2010). Thus, it is important to control for these characteristics when evaluating the effect of private equity transactions on growth and reallocation outcomes.

The huge number of firms and establishments in the LBD allows us to control for a full set of interactions among industry, size, age, multi-unit status, and transaction year. We sort 
target firms into cells defined by the cross product of these characteristics. ${ }^{8}$ We then identify all firms in the LBD not backed by private equity that fall into the same cell as a given target firm, and we treat those firms as controls. Specifically, we control for the interaction of 72 two-digit industries, 10 firm size categories, 6 firm age categories, a binary indicator for firms with multiple establishments, and 24 distinct transaction years. The cross product of these categorical variables yields over 8,000 control cells per year. Of course, many cells are unpopulated, but the richness of our controls is evident. In our regression analysis, we also control for pre-transaction employment growth histories. We follow the same approach in the establishment-level analysis. To obtain controls for a given target establishment, we select all establishments in the same control cell from among the set of active establishments in the transaction year, excluding establishments owned by a firm under private equity control.

A related choice involves our statistical approach to estimating the effects of private equity transactions on employment outcomes. We consider nonparametric comparisons that control for the cross-product of our categorical variables, semi-parametric regressions that include additional controls, and propensity score methods. Ideally, we would like to estimate the average treatment effect on the treated, i.e., the average effect of private equity buyouts on target firms. As discussed in Woolridge (2002, chapter 18), consistent estimation of average treatment effects requires conditional mean independence: conditional on the controls and the treatment indicator, outcomes for the treated and non-treated are independently distributed. Compared to previous research, our rich set of controls lends greater plausibility to this identifying assumption.

\footnotetext{
${ }^{8}$ We define industry for multi-unit firms based on the modal industry of their establishments, computed on an employment-weighted basis.
} 
Even if one questions the assumption of conditional mean independence, our study yields a rich set of new findings about employment outcomes at private equity targets. These findings throw light on alternative views about the economic role of private equity, as we discuss below. Our findings also provide useful evidence for formulating and evaluating theoretical models of private equity behavior and effects.

A fourth choice relates to the time window around private equity transactions. Our establishment-level analysis considers employment outcomes for five years on either side of a private equity transaction. Five years is a typical holding period for target firms (Stromberg 2007). For our firm-level analysis, we must confront the reorganization of firms through mergers, ownership changes, partial divestitures, and acquisitions of establishments from other firms. Because it tracks both firms and establishments over time and contemporaneously links establishments to firms, the LBD offers greater scope for identifying these changes than most other business-level datasets. Nevertheless, some private equity targets undergo complex postbuyout restructurings that challenge the maintenance of high-integrity longitudinal links. We deal with this challenge in two ways. First, our firm-level analysis considers a relatively short window of two years after each buyout transaction, thereby limiting the linkage issues that arise from complex firm-level reorganizations. Second, we use our establishment-level data to assess the impact of potential sample selection bias in our firm-level analysis.

Before proceeding, we define our employment and growth rate measures. Let $E_{i t}$ be employment at establishment or firm $i$ in year $t$; i.e., the number of workers on the payroll in the pay period covering March 12. The employment growth rate is $g_{i t}=\left(E_{i t}-E_{i t-1}\right) / X_{i t}$, where 
$X_{i t}=.5 *\left(E_{i t}+E_{i t-1}\right) .{ }^{9}$ The employment growth rate at any higher level of aggregation is the weighted mean of establishment or firm growth rates given by $g_{t}=\sum_{i}\left(X_{i t} / X_{t}\right) g_{i t}$, where $X_{t}=\sum_{i} X_{i t}$. We consider the respective contributions of expanding and shrinking establishments, establishment entry and exit, and acquisitions and divestitures to firm-level employment changes, and compare outcomes between targets and controls on each of these adjustment margins.

\section{Establishment-Level Analysis}

\section{A. Nonparametric Comparisons}

We begin with an "event study" that compares outcomes at target establishments to outcomes at control establishments. To encompass a five-year window before and after buyout years, we consider transactions in the 1980-2000 period. As discussed above, we construct control cells as the cross product of industry, size of parent firm, age of parent firm, multi-unit status, and transaction year. Our firm size categories are 1-4, 5-9, 10-19, 20-49, 50-99, 100-249, 250-499, 500-999, 1000-2499, 2500-4999, 5000-9999, and 10000 or more employees. Our firm age categories are $0-5$ years, $6-10,11-15,16-20$, and 21 or more years. ${ }^{10}$ We use firm size and age measures to facilitate comparisons to our firm-level analysis below. Replacing firm size and age measures with establishment measures yields similar results.

The solid curve in Figure 5a shows the employment path of target establishments around the transaction year. Establishments that came under private equity ownership between 1980 and 2000 employed 2.3 million workers as of the transaction year. The dashed curve shows the

\footnotetext{
${ }^{9}$ This growth rate measure has become standard in analyses of establishment and firm dynamics, because it shares some useful properties of log differences while also accommodating entry and exit. See Davis et al. (1996) and Tornqvist, Vartia, and Vartia (1985) for discussion.

${ }^{10}$ Following Davis et. al. (2009), when a firm first appears in the LBD, we assign it the age of its oldest establishment. We then increment the firm's age by one year for each year it continues as a legal entity in the LBD. In this way, we avoid arbitrary increases or decreases in firm age due to the sale and purchase of establishments.
} 
counterfactual path of employment at targets had they grown at the same rate as controls. To construct this counterfactual, we first rescale the employment of controls to match that of targets cell by cell in the transaction year. We then apply the actual growth rates of the controls to generate the dashed curve. ${ }^{11}$ Comparing the solid and dashed curves highlights the critical need to evaluate target outcomes relative to controls. In particular, a simple difference-in-difference analysis of target outcomes before and after transaction years would produce a highly misleading impression about the employment effects of private equity buyouts.

Figure 5b tracks mean employment growth rate differences between target and control establishments from 5 years before to 5 years after the transaction year. Perhaps surprisingly, Figure 5b shows no systematic pattern of slower job growth at targets in the years leading up to buyout transactions. In the transaction year itself, employment growth at targets is actually 2 percentage points higher than at controls. However, there is a clear pattern of slower growth at targets post buyout, with growth differentials ranging from $0.5 \%$ to $2 \%$ per year. These differentials cumulate to $3.2 \%$ of employment in the first two years post buyout and $6.4 \%$ over five years. These results accommodate heterogeneous treatment effects over the cross product of industry, firm size, firm age, multi-unit status, and year of transaction. They recover the average treatment effect on the treated under the assumption of conditional mean independence, as we discussed above.

Previous research finds very large gross job flows relative to net employment changes (Davis and Haltiwanger, 1999), raising the question of how employment responds to private equity transactions on job creation and destruction margins. Figure 6 tells an important story in this regard: Slower employment growth at private equity targets post buyout entirely reflects a

\footnotetext{
${ }^{11}$ To be precise, we calculate the weighted mean growth rate over cells using the weights defined at the end of Section 4. The cell-level weights evolve over time in line with the growth experiences of targets (solid curve) and controls (dashed curve). For cells with multiple controls, each control receives equal weight.
} 
greater pace of job destruction. Indeed, gross job creation rates are greater at target establishments in the wake of buyouts. These results are interesting for at least two reasons. First, they indicate that private equity buyouts accelerate the pace of employment change on destruction and creation margins, a theme we return to below. Second, Figure $6 \mathrm{~b}$ confirms that jobs at target establishments are at greater risk post buyout than jobs at controls. As seen in Figure 7, about half of this greater risk reflects a higher post-buyout shutdown propensity at target establishments.

\section{B. Regression Analysis}

We turn now to a regression analysis that allows for additional controls and an easy calculation of standard errors in the estimated effects of private equity transactions. Table 3 reports establishment-level regression results for the transaction year and five subsequent years. Each regression involves the matched target establishments in transactions from 1980 to 2000 and their corresponding control establishments. The dependent variable is the employment growth rate in the indicated year following the buyout. The first column in Table 3 reports the mean growth rate differentials from Figure 5b. The second and third columns report results for semi-parametric regressions that include controls for the pre-buyout growth history of parent and target firms.

We include two variables to control for pre-buyout history. One variable considers the set of establishments owned by the target firm as of year 0 (the transaction year). We set the value of this variable to the employment growth rate of these establishments from year -3 to year

-1. A second variable considers the parent firm that owned these establishments in year -3 . If ownership was split across multiple firms in year -3, we select the firm with the largest share of employment among these establishments. We then set the second variable to the employment 
growth rate of that firm from year -3 to year -1 . Often, but not always, these two control variables take on the same value.

The Table 3 regressions contain a large battery of additional controls. The column headed “ATE=ATE1” includes a fully interacted set of controls for two-digit industry, firm size, firm age, multi-unit status, and year. This specification posits a common treatment effect, given by the coefficient on an indicator variable for target establishments in private equity transactions. The column headed “ATE1 Heterogeneous” includes the same set of controls, but relaxes the assumption of uniform treatment effects by interacting the private equity indicator with the 6 firm age categories, 10 firm size categories, and the two measures of pre-buyout growth history. This specification is more restrictive than the nonparametric specification in some respects but less restrictive in the inclusion of controls for pre-buyout growth history and in allowing the treatment effect to vary with pre-buyout employment growth. To recover the average treatment effect on the treated in this case, we compute a weighted average of the heterogeneous estimated treatment effects, using cell-level employment weights of targets in the transaction year. We calculate standard errors by the Delta method.

As seen in Table 3, the nonparametric and semi-parametric specifications deliver similar results. The two semi-parametric regressions also yield small standard errors and tightly estimated effects of private equity transactions. Five-year cumulative employment losses at targets range from $-4.7 \%$ to $-6.4 \%$, depending on specification, with somewhat smaller losses in the semi-parametric specifications. ${ }^{12}$ In short, the evidence says that private equity buyouts lead to deeper job losses at establishments in operation as of the transaction year.

\footnotetext{
${ }^{12}$ Smaller losses in the semi-parametric specifications point to a modest tendency for private equity to target firms with weaker employment growth prospects, which differs somewhat from the inference suggested by the pre-buyout comparison in Figure 5b. Recall that Figure 5 involves a comparison of growth rates between target and control establishments. In contrast, the semi-parametric regressions reported in Table 3 contain controls for the pre-buyout growth history of parent firms.
} 


\section{Firm-Level Analysis}

\section{A. Tracking Firms}

Section 5 considers outcomes for establishments owned by target firms at the time of the deal. We now shift to a firm-level analysis to capture new establishments opened after the deal as well as post-buyout acquisitions and divestitures. By necessity, we restrict attention to target firms that we can track post buyout. While we can readily track establishments over time in the LBD, tracking firms is more challenging for two reasons: the disappearance of firm identifiers (IDs) in some circumstances, and irregularities in Census Bureau tracking of private equity targets involved in divisional sales.

The disappearance of a firm identifier (ID) in the LBD can occur for various reasons. One is the death of a firm and closure of its establishments. Firm death in this sense presents no problem for our analysis, and we capture such events whether they involve target or control firms. A more difficult situation involves a firm ID in year 0 that disappears in later years, even though some of the establishments owned by the firm continue to operate. This situation can arise because of a merger or complex reorganization (e.g. different components of the original firm are bought by multiple existing firms). It is inherently difficult to define and measure firm growth when the original legal entity has ceased to exist, and we exclude these observations in our firm-level analysis. To reduce the number of observations lost for this reason, we limit our firm-level analysis to years 1 and 2 after the transaction.

In the course of our data development and analysis, we discovered that the Census Bureau did not accurately track firm IDs in certain private equity transactions. Inaccuracies sometimes occurred when a private equity group acquired one or more divisions of a corporate entity, but not the whole firm. In principle, the Census Bureau's Annual Company Organization Survey (sent to all large multi-unit companies) yields data that enables the Census to track these 
divisional sales. However, we identified divisional sales in which the firm ID of the (new) target firm remained the same as the ID of the selling firm. This problem did not affect the establishment-level analysis in Section 5, because we could rely on an alternative identifier - the Employer Identification Number (EIN) - to accurately identify, as of the transaction year, establishments involved in divisional sales. Unfortunately, EINs are unsuitable for tracking firms post buyout because new and acquired establishments may obtain new EINs. In light of this issue, we exclude divisional cases from our firm-level analysis for those cases when Census does not provide an accurate ID for the target firm.

We more fully discuss tracking issues related to divisional sales and our use of EINs in the web appendix. ${ }^{13}$ The web appendix also repeats the establishment-level analysis of Section 5 excluding establishments owned by divisional targets with inaccurate IDs. The pattern of results for this subsample is quite similar to the results in Section 5, although the subsample yields somewhat smaller employment losses at targets relative to controls. The similarity of the establishment-based results for the full sample and the subsample suggests that our firm-level analysis is not seriously distorted by the inability to accurately track firm IDs for some divisional sales.

For the firm-level analysis, we expand the sample period to run through $2003 .{ }^{14}$ Table 2 reports summary statistics for various firm-level samples. Our full matched sample contains 2265 target firms from 1980 to 2003. They account for about 4.3 million workers and 104,000 establishments as of the transaction year. Excluding the divisional, EIN cases that lack accurate firm IDs yields 1,874 target firms with about 3.4 million workers and 79,000 establishments. ${ }^{15}$

\footnotetext{
13 The web appendix can be found at http://econweb.umd.edu/ haltiwan/papers.htm.

${ }^{14}$ A firm-level analysis for the period from 1980 to 2000 yields similar results.

15 Although our firm-level analysis sample excludes some transactions covered by the establishment-level analysis, extending the sample period through 2003 captures a large number of more recent transactions, as seen in Figures 1 and 2. As a result, the firm-level analysis sample actually covers more employment.
} 
Further restricting attention to firms that we can track for two years after the buyout year, including deaths, yields a sample of 1,374 firms and 3.2 million workers. This sample represents 73 percent of the matched sample with accurate firm IDs and 93 percent of their employment. The latter statistic is more relevant given our focus on employment-weighted outcomes.

\section{B. Firm-level Results}

Our firm-level analysis considers the same type of semi-parametric regression specifications as in Table 3. Now, however, we explore employment responses on several adjustment margins, including the entry of new establishments post buyout. As before, the regressions include the pre-buyout growth variables and the cross product of industry, firm size categories, firm age categories, multi-unit status, and transaction year as controls. We weight observations by employment, as before. To obtain the effect of interest, we rely on indicator variables for target firms. Table 4 presents the firm-level regression results for cumulative responses over the first two years post buyout.

The top row in Table 4 shows results using firm-level employment growth rates as the dependent variable. Again, we report results for an ATE=ATE1 specification that posits a uniform treatment effect, and for an ATE1 Heterogeneous specification that allows treatment effects to vary with pre-buyout history and across firm age and size categories. The top row in Table 4 says that target firms shrink more rapidly than controls in the two-year period after buyouts - by 0.88 percentage points in the ATE=ATE1 specification and 0.65 percentage points in the ATE1 Heterogeneous specification. These estimated effects are much smaller than the cumulative two-year differences of 2.5 and 2.9 points, respectively, in Table 3. This comparison suggests that the additional adjustment margins captured by the firm-level analysis alters the picture of how private equity transactions affect employment outcomes. 
The remaining rows in Table 4 address the issue directly in the firm-level sample. Focus on the ATE1 Heterogeneous specification, and consider first the results for "Continuers" and "Deaths". These are the adjustment margins captured in the establishment-level analysis. ${ }^{16}$ Summing these two components yields a two-year employment growth rate differential of -5.49 percentage points $(-1.36-4.13)$ for targets, a large difference. But target firms create more new jobs at new establishments in the first two years after buyouts, a difference of 1.87 points in favor of targets. Combining these three adjustment margins yields a differential of -3.62 percentage points for targets. Finally, bringing in the role of acquisitions and divestitures reduces this differential to -0.81 points, close to the estimated differential in the top row. ${ }^{17}$ Thus, the overall impact of private equity transactions on firm-level employment growth is quite modest.

Another noteworthy aspect of Table 4 involves the intensity of reallocation activity at target firms. In particular, target firms exhibit substantially greater job destruction in establishment shutdowns, more job creation at establishment births, more employment losses through divestitures, and greater employment gains through acquisitions. In other words, target firms undergo more job reallocation activity post buyout than control firms. These results support the view that private equity is a catalyst for creative destruction as measured by job creation and destruction and the purchase and sale of business units. We develop this theme more fully in the next section.

As a robustness check, we also estimate the average treatment effect of private equity buyouts on firm-level employment growth using propensity score methods. We construct propensity scores by fitting logit specifications, one for each transaction year, for the likelihood

\footnotetext{
${ }^{16}$ Note that for this to be fully comparable it would have to include establishments that were divested but continue to operate under different ownership.

${ }^{17}$ The control variables take on different values in different rows of Table 4, so the estimated effects for the various adjustment margins need not sum to the exact value of the net estimated effect in the top row.
} 
that a firm becomes a private equity target. The logit specification includes the pre-buyout growth variables and the cross product of industry, firm size categories, firm age categories, and multi-unit status. Our second-stage regression includes an indicator for private equity targets, as before, plus the propensity score measure interacted with year effects. Using this second-stage regression, we estimate that a private equity buyout raises firm-level employment growth by 0.26 percentage points in the first two years post buyout, with a standard error of 0.18 points. ${ }^{18}$ Thus, under the propensity score approach, we cannot reject the hypothesis that private equity transactions have zero net impact on employment growth at target firms.

To conclude this section, it is worth stressing that our firm-level and establishment-level regression analyses answer different questions. The establishment-level analysis tells us what happens to employment at establishments owned by target firms as of the transaction year. The firm-level analysis tells us what happens to employment at target firms, overall and on various adjustment margins. In practice, the main difference is that the firm-level analysis picks up large differentials between targets and controls in job creation at newly opened establishments and in employment changes associated with acquisitions and divestitures. More subtle differences are also present. Consider, for example, a target establishment sold to another firm one year after the buyout transaction. Employment changes at this firm from year 1 to year 2 are captured in the establishment-level analysis but not the firm-level analysis.

\section{Private Equity: Agents of Change or Agents of Restructuring?}

Table 4 and Figure 6 provide evidence that private equity transactions function as catalysts for creative destruction. This evidence is consistent with two distinct hypotheses. One

\footnotetext{
${ }^{18}$ The standard errors are not adjusted for the first-stage estimation. As Woolridge (2002) notes, an advantage of including controls directly in the main regression is that it simplifies the computation of standard errors. He also points out that propensity score methods often yield similar results to methods that use controls in the main regression. When estimated with a linear probability model, a propensity score approach is equivalent to a one-stage approach that introduces the controls directly into the main regression.
} 
hypothesis holds that private equity acts as an agent of change - inducing some target firms to expand relative to controls and others to retrench. According to this hypothesis, our earlier evidence reflects a combination of (a) upsizing target firms that add establishments and jobs more rapidly than controls and (b) downsizing target firms that shed jobs and establishments more rapidly than controls. The positive effects of buyouts on creation, destruction, acquisitions, and divestitures then result by aggregating over upsizing and downsize cases. An alternative hypothesis holds that private equity acts as an agent of restructuring within target firms, accelerating the reallocation of jobs across establishments of target firms and the pace of their divestitures and acquisitions. According to this hypothesis, the positive effects of buyouts on gross job flows, acquisitions, and divestitures occur within target firms. These hypotheses are not exclusive because private equity may accelerate both types of creative destruction.

To investigate these hypotheses, we estimate the impact of private equity transactions on various firm-level measures of reallocation activity in the wake of buyouts. The overall job reallocation rate for a firm is the sum of its gross job gains due to new, expanding, and acquired establishments and its gross job losses due to exiting, shrinking, and divested establishments. A firm's excess reallocation rate is the difference between its job reallocation rate and the absolute value of its net growth rate. ${ }^{19}$ If a given firm changes employment in the same direction at all of its establishments, then its excess reallocation is zero. To the extent that a firm expands employment at some units and contracts employment at others, it has positive excess reallocation. If the firm adds jobs at some of its establishments and cuts an equal number of jobs at other establishments, then excess reallocation equals job reallocation.

\footnotetext{
${ }^{19}$ This concept of excess reallocation is often used in the literature on gross job flows to analyze the nature of job reallocation within and between industries or sectors. See Dunne, Roberts, and Samuelson (1989), Davis and Haltiwanger (1992), and, for a review of the literature, Davis and Haltiwanger (1999). Our approach here applies the concept to the reallocation of jobs across units within firms.
} 
By estimating the impact of private equity transactions on excess and job reallocation rates at target firms (relative to controls), we can quantify the extent to which private equity acts as an agent of change or an agent of restructuring. For example, if private equity acts exclusively as an agent of change, then the entire creative destruction response of target firms involves higher job reallocation but no impact on firm-level excess reallocation. At the other extreme, if private equity acts exclusively as agents of restructuring within target firms, then firm-level job reallocation and excess reallocation rates respond by the same amount to private equity transactions.

Table 5 reports regression results for firm-level job reallocation and excess reallocation rates using the same specifications and two-year horizon as in Table 4. In the ATE1 Heterogeneous specification, the reallocation rate is 5.0 percentage points higher at targets for organic employment changes and 13.3 points higher when including acquisitions and divestitures. These results confirm our previous inference that private equity transactions substantially accelerate the pace of creative destruction activity at target firms. The excess reallocation rate is 5.6 points higher at target firms for organic changes, 8.8 points higher with acquisitions and divestitures. The implication is that the increase in job reallocation induced by buyout transactions mainly involves an accelerated pace of restructuring within target firms. For organic changes, the impact of buyouts on excess reallocation is actually greater than the impact on job reallocation. ${ }^{20}$ Thus, especially for organic employment changes, our evidence implies that private equity acts predominantly as an agent of restructuring within target firms.

A limitation of the regression estimates in Tables 3, 4, and 5 is that they identify only the differences between targets and controls. To recover information about the levels of creation and

\footnotetext{
${ }^{20}$ By definition, overall job reallocation equals or exceeds job reallocation for a given firm or group of firms. Our comparison here, however, involves the difference between job reallocation and excess reallocation responses for two distinct sets of firms, targets and controls.
} 
destruction activity, we return to the nonparametric approach of section 5 and consider a counterfactual exercise along the lines of Figure 5. Specifically, we sort target and control observations in our 1980-2003 firm-level analysis sample into cells defined by the same cross product of industry, size, age, multi-unit status, and transaction year as before. For each cell, we calculate cumulative two-year changes post buyout for each employment adjustment margin. We do this separately for targets and controls. We then generate the weighted average outcomes for targets and controls using the same approach to weighting as in Figure 5. These calculations reveal the extent of creation and destruction activity on each adjustment margin at target firms, and they tell us how target firm activity would differ if they exhibited the same behavior as controls.

We report the results of these calculations in Table 6. They show high rates of creation and destruction at target firms in the wake of private equity transactions. The two-year cumulative job reallocation at target firms is 39 percent of employment for organic changes (Panel A) and 57 percent with acquisitions and divestitures (Panel B). The large role of establishment entry and exit at targets is especially striking. Greenfield entry accounts for 72 percent of organic job creation at target firms, and establishment closures account for 66 percent of organic job destruction. The pace of job creation and destruction due to establishment births and deaths is considerably slower at control firms.

According to the "Difference" column in Panel A of Table 6, buyouts raise job creation, destruction and reallocation rates by, respectively, 1.8, 3.9 and 5.8 percent of transaction-year employment, which amount to 11, 20 and 17 percent of the base rates at control firms. Panel B shows that the increases in creation, destruction, and reallocation associated with buyouts are considerably larger, in both absolute and relative terms, when including acquisitions and divestitures. In short, we find that private equity buyouts accelerate the pace of firm-level 
restructuring on every adjustment margin we measure. To check the consistency of these results with the semi-parametric regressions in Tables 4 and 5, the two rightmost columns in Panels A and B report the regression estimates of target-control differences. The two approaches yield very similar differences, and the differences are precisely estimated.

Panel C summarizes the information in a different way by decomposing job reallocation separately for targets and controls. The two-year job reallocation rate is 57 percent at targets and 43 percent at controls. Organic components account for about 70 percent of job reallocation at targets and a larger percent at controls. Moreover, the organic component of within-firm excess reallocation accounts for a large share (about 35 percent) at both sets of firms. Acquisitions and divestitures account for a larger share of job reallocation at targets.

\section{Differential Responses by Period, Industry and Target Type}

Thus far, we have characterized responses to private equity transactions for the private sector as a whole, and obtained similar results whether we posit uniform or heterogeneous treatment effects. Nevertheless, our earlier analysis may obscure important differences in responses to private equity buyouts by time period, industry, or type of transaction. We now investigate these differences, drawing on previous accounts and research for inspiration as to where there might be important differences.

Descriptive accounts suggest that private equity groups shifted to a more operational orientation over time, which could lead to time-varying responses at targets. The scale of private equity buyout activity also increased enormously over time, which could alter the character of the marginal target and its post-buyout performance. Motivated by these observations, in the web appendix we analyze the mean growth rate differences between private equity targets and control establishments for three periods. The findings (see Figure B.2 of the web appendix) show that the main pattern documented earlier also holds for transactions in the 1980s, the 1990- 
94 period, and the 1995-2000 period. In each period, employment contracts more rapidly at targets than at controls in the years following buyout transactions.

Some accounts of private equity buyouts paint a picture of aggressive cost cutting through layoffs. This characterization suggests the potential for bigger job destruction responses to private equity buyouts in labor-intensive industries, reflecting the view that aggressive cost cutters focus on the biggest cost sources. More generally, there are major differences in factor input shares, market structure, demand conditions, and labor relations across industries that might lead to important differences in the responses to private equity buyouts. Motivated by these ideas, Figure 9 displays results for three broad industry sectors that cover most private equity transactions. Employment falls modestly at target establishments relative to controls post buyout in manufacturing. Accounting for transaction-year outcomes as well, there is no material cumulative jobs effect of buyout transactions in the manufacturing sector. Retail Trade exhibits a markedly different response pattern. In the years leading up to buyout transactions, controls and targets in the Retail Trade sector exhibit similar employment growth rates. Post buyout, however, employment at target establishments falls by nearly 12 percent relative to controls over five years. The Service sector exhibits yet a different pattern. Targets grow much rapidly than controls prior to the transaction year but somewhat more slowly afterwards. Figure 9 serves as a caution against painting with an overly broad brush when characterizing employment outcomes in the wake of private equity buyouts.

There are also good reasons to think that employment responses vary by type of transaction. For example, a desire to ease capital constraints and improve funding access may be more prevalent among independent firms that are privately held before the buyout. Public-toprivate deals may be more likely to involve target firms with a strong need for cost cutting, as in the Beatrice case discussed by Baker (1992). Alternatively, there could be a higher incidence of 
poor execution in public-to-private deals. Kaplan and Stromberg (2009) stress that large publicto-private deals are concentrated at market peaks, where high valuations and extreme leverage levels are commonplace, and these transactions seem to encounter a disproportionate share of difficulties. For instance, Andrade and Kaplan (1998) find that 23\% of larger public-to-private transactions in the 1980s defaulted at some point. Guo et al. (2011) find weak operating performance in a sample of public-to-private transactions undertaken in the first half of the 2000s.

Motivated by these arguments, Table 7 reports the estimated effects of buyouts by type of private equity transaction based on our ATE1 Heterogeneous regression specification. We report results for the response of the firm-level employment growth rate and the response on each adjustment margin. Each coefficient in Table 7 corresponds to the estimated average treatment effect on the treated in the indicated regression. As in the earlier firm-level results, we focus on changes over a two-year horizon post buyout.

Inspecting the top row in Table 7, employment growth rate responses differ greatly by type of private equity transaction. In public-to-private transactions, target employment contracts by more than 10 percent relative to controls over two years. Target firms in public-to-private transactions experience substantially greater job losses due to establishment deaths and divestitures. They also experience less job creation through establishment births. Along with the high visibility of public-to-private deals, these results help to understand concerns about job loss related to private equity buyouts.

In striking contrast, employment at independent targets (also known as private-to-private deals) grows 10 percent relative to controls in the first two years post buyout. More rapid employment growth at independent targets reflects a higher pace of acquisition, consistent with the view that private equity investments facilitate firm-level expansion. It is worth stressing that 
most buyout transactions involve independent targets, even though public-to-private transactions garner much more attention. In terms of transaction-year employment, independent targets account for about 63 percent more jobs than publicly held targets (Table 2).

Table 7 also shows that divisional buyouts involve a pattern of results broadly similar to the ones in Tables 4 and 5 - modest net employment contractions at targets relative to controls and substantially higher rates of creation, destruction, acquisitions, and divestitures. Secondary transactions involve net employment gains at targets relative to controls and a very high pace of excess reallocation driven, largely due to an extraordinary pace of creation at birth and destruction at deaths. Secondary buyouts account for a modest 11 percent of transaction-year employment for transactions that occurred from 1980 to 2003, and Other buyouts account for only 3 percent.

One common pattern emerges for all deal types in Table 7: excess reallocation rates are higher at target firms than at controls. The magnitude of the target-control difference in excess reallocation varies greatly by type of transaction, but it is positive and highly statistically significant in all cases. This result says private equity acts as an agent of restructuring at target firms in all of the transaction types we identify.

\section{Conclusions and Directions for Future Research}

Our study examines employment responses to private equity buyouts at a much more granular level than earlier work. Compared to previous research, we exploit a much larger sample of transactions, a much more extensive set of controls, and a novel ability to track outcomes at firms and establishments. These advantages enable us to overcome important limitations in previous research and address controversies about employment outcomes. We also exploit the strengths of our data to explore new questions about private equity's role in the creative destruction process and its impact on restructuring activity inside target firms. 
Our findings support the view that private equity deals lead to greater job loss at establishments operated by target firms as of the transaction year. Employment at these establishments shrinks by 3 percent relative to controls in the two-year period post buyout and by 6 percent over five years. Gross job destruction at these target establishments outpaces destruction at controls by a cumulative 10 percentage points over five years post buyout. These results say that pre-existing employment positions are at greater risk of loss in the wake of private equity buyouts.

While noteworthy, these results make up only part of a richer and more interesting story about the employment effects of private equity. Using our ability to track each firm's constituent establishments, we estimate how employment responds to private equity buyouts on several adjustment margins, including job creation at greenfield establishments opened post buyout. This aspect of our analysis reveals that target firms create new jobs in greenfield establishments at a faster pace than control firms. Accounting for greenfield job creation erases about one-third of the net employment growth differential in favor of controls. Accounting for the purchase and sale of establishments as well, the employment growth differential is less than 1 percent of initial employment over two years.

Private equity buyouts involve much larger effects on the gross creation and destruction of jobs - both in the form of organic employment changes and in the acquisition and divestiture of establishments. The job reallocation rate at target firms exceeds that of controls by 13.5 percentage points over two years post buyout. About 43 percent of the extra job reallocation reflects a more rapid pace of organic employment adjustments, and the rest reflects acquisitions and divestitures. These novel findings provide evidence that private equity buyouts catalyse the creative destruction process as measured by gross job flows and the purchase and sale of business establishments. 
Digging deeper, we also address two distinct hypotheses about the nature of the increased creative destruction activity associated with private equity buyouts. One hypothesis sees private equity as agents of change in the sense that buyouts accelerate retrenchments at some target firms and they accelerate expansion at others. Another hypothesis sees private equity as agents of restructuring in the sense that buyouts accelerate the reallocation of jobs across establishments within target firms. We show that the restructuring effect predominates, especially for organic employment changes.

Finally, we provide evidence that employment responses to private equity buyouts vary considerably across industries and by type of transaction. The largest employment losses at targets relative to controls occur in Retail Trade. Public-to-private deals, which tend to be highly visible, also involve large employment losses at targets relative to controls. In contrast, independently owned firms exhibit large employment gains relative to controls in the wake of buyouts, mainly due to greater acquisitions. Private equity buyouts of independent firms are more numerous than public-to-private transactions, and they account for a larger share of jobs.

By identifying a large sample of private equity transactions and linking them to the LBD, this paper also sets the stage for new research into the effects of private equity transactions on capital expenditures, productivity growth, compensation, profitability, and other outcomes. Simple measures of labor compensation and output per worker are available directly from the LBD. A much richer array of input and outcome measures are available at the firm and establishment level in other Census Bureau data sets that can be linked to the LBD and our dataset of private equity transactions. One example is the Longitudinal Research Database, a rich and widely used longitudinal source of data on manufacturing establishments. Currently, we are using the LRD in combination with the dataset we constructed for this paper to study wage and productivity effects of private equity buyouts. 
In future work, we plan to examine employment and productivity outcomes in corporations that sell to private equity groups. Many divisional buyouts involve divestitures of underperforming units that may place heavy demands on senior management. Schoar (2002) documents that acquisitions can lead managers to neglect core businesses, a phenomenon she calls the "new toy" effect. The LBD will allow us to observe whether the same pattern operates in reverse when firms sell underperforming or poorly fitting divisions, thereby freeing senior management to focus on core activities.

Finally, we wish to highlight the need to investigate experiences outside the United States. While U.S. private equity outcomes are especially interesting because of the industry's large size and maturity, the U.S. experience may not reflect experiences in other countries. The impact of private equity might differ across environments depending on corporate governance, financial depth, legal institutions, and economic development. While they lack our combination of firm-level and establishment-level data, recent works by Amess and Wright (2007) and Boucly, Sraer, and Thesmar (2009) also consider employment outcomes in the wake of private equity transactions, using data for the United Kingdom and France, respectively. 


\section{References}

Amess, K. and M. Wright (2007), "The Wage and Employment Effects of Leveraged Buyouts in the UK,” International Journal of the Economics of Business 14, 179-195.

Andrade, G. and S.N. Kaplan (1998), "How Costly is Financial (not Economic) Distress?

Evidence from Highly Levered Transactions that Became Distressed,” Journal of Finance 53, 1443-1493.

Baker, G.P. (1992), “Beatrice: A Study in the Creation and Destruction of Value,” Journal of Finance 47, 1081-1120.

British Venture Capital Association (BVCA) (2006), The Economic Impact of Private Equity in the UK, London, BVCA.

Boucly, Q., D. Sraer, and D. Thesmar (2009), "Leveraged Buyouts: Evidence From French Deals,” Unpublished working paper, HEC Paris and University of California at Berkeley.

Caballero, Ricardo (2007), Specificity and the Macroeconomics of Restructuring, Cambridge, MA: The MIT Press.

Caves, Richard E. (1998), "Industrial Organization and New Findings on the Turnover and Mobility of Firms,” Journal of Economic Literature, 36, no. 4 (December), 1947-1982.

Davis, S.J. and J. Haltiwanger (1992), “Gross Job Creation, Gross Job Destruction, and Employment Reallocation” Quarterly Journal of Economics 107, no. 3 (August), 819-863.

Davis, S.J., J. Haltiwanger (1996), Job Creation and Destruction, Cambridge, MA: The MIT Press.

Davis, S.J. and J. Haltiwanger (1999), "Gross Job Flows," in Card, D. and O. Ashenfelter (eds.), Handbook of Labor Economics, New York, North-Holland.

Davis, S.J., J. Haltiwanger, R. Jarmin, C.Z. Krizan, J. Miranda, A. Nucci, and K. Sandusky (2009), "Measuring the Dynamics of Young and Small Businesses: Integrating the Employer and Non-employer Business Universes,” in Dunne, T., J.B. Jensen and M.J. Roberts (eds.), Producer Dynamics: New Evidence from Micro Data, University of Chicago Press, 329-368.

Davis, S.J., J.C. Haltiwanger, R. Jarmin, and J. Miranda (2007), "Volatility and Dispersion in Business Growth Rates: Publicly Traded versus Privately Held Firms,” in Acemoglu, D., K. Rogoff and M. Woodford (eds.), NBER Macroeconomics Annual 21, 107-180.

Dunne, T., M. Roberts, and L. Samuelson (1989) "Plant Turnover and Gross Employment Flows in the U.S. Manufacturing Sector,” Journal of Labor Economics 7, 48-71. 
European Private Equity and Venture Capital Association (EVCA) (2005), Employment Contribution of Private Equity and Venture Capital in Europe, Zaventum, Belgium, EVCA.

Guo, S., E.S. Hotchkiss, and W. Song (2011), “Do Buyouts (Still) Create Value?,” Journal of Finance, 66, 479-517.

Hall, D. (2007), "Methodological Issues in Estimating the Impact of Private Equity Buyouts on Employment," Unpublished working paper, Public Services International Research Unit, Business School, University of Greenwich.

Haltiwanger, J., R. Jarmin and J. Miranda (2010), "Who Creates Jobs? Small vs. Large vs. Young,” Working Paper no. 16300, National Bureau of Economic Research.

Harris, R., D.S. Siegel and M. Wright (2005), "Assessing the Impact of Management Buyouts on Economic Efficiency: Plant-Level Evidence from the United Kingdom,” Review of Economics and Statistics 87, 148-153.

Jensen, M.C. (1989), "The Eclipse of the Public Corporation,” Harvard Business Review 67 (September-October), 61-74.

Kaplan, S.N. (1989), "The Effects of Management Buyouts on Operating Performance and Value,” Journal of Financial Economics 24, 217-254.

Kaplan, S.N. and P. Strömberg (2009), "Leverage Buyouts and Private Equity,” Journal of Economic Perspectives, 23(1), 121-146.

Kearney, A.T. (2007), Creating New Jobs and Value with Private Equity, Chicago, A. T. Kearney.

Lichtenberg, F.R. and D. Siegel (1987), "Productivity and Changes in Ownership of Manufacturing Plants,” Brookings Papers on Economic Activity: Microeconomics, 643-683.

Lichtenberg, F.R. and D. Siegel (1990), "The Effects of Leveraged Buyouts on Productivity and Related Aspects of Firm Behavior," Journal of Financial Economics 27, 165-194.

Long, W. and D. Ravenscraft (1993), "The Financial Performance of Whole Company LBOs," Working paper no. CES-WP-93-16, Center for Economic Studies, U.S. Census Bureau.

McGuckin, R.H. and S.V. Nguyen (2001), "The Impact of Ownership Changes: A View from Labor Markets,” International Journal of Industrial Organization 19, 739-762.

Muscarella, C.J. and M.R. Vetsuypens (1990), "Efficiency and Organizational Structure: A Study of Reverse LBOs,” Journal of Finance 45, 1389-1413.

Rasmussen, P.N. (2008), “Taming the Private Equity ‘Locusts’, "Europe Today 8 (Spring), 130133. 
Schoar, A. (2002), "Effects of Corporate Diversification on Productivity," Journal of Finance 57, 2379-2403.

Service Employees International Union (SEIU) (2007), Behind the Buyouts: Inside the World of Private Equity, Washington, SEIU.

Shapiro, R.J., and N.D. Pham (2008), American Jobs and the Impact of Private Equity

Transactions, Washington, Private Equity Council.

Shleifer, A. and L. Summers (1988), "Breach of Trust in Hostile Takeovers,” in Auerbach, A.J. (ed.), Corporate Takeovers: Causes and Consequences, Chicago, University of Chicago Press.

Strömberg, P. (2007), “The New Demography of Private Equity,” Unpublished working paper, Swedish Institute for Financial Research.

Taylor, A. and C. Bryant (2007), "Private Equity Deals that Cement Business Growth,” Financial Times, 2 April.

Tornqvist, L., P. Vartia, and Y. Vartia (1985), "How Should Relative Change Be Measured?,” American Statistician 39 (February), 43-46.

Woolridge, J. M. (2002), Econometric Analysis of Cross Section and Panel Data, Cambridge: MIT Press.

Wright, M., S. Thompson, and K. Robbie (1992), "Management-Led Leveraged Buy-Outs: A European Perspective,” Journal of Business Venturing 7, 45-71. 
Figure 1: Matches of Private Equity Targets to LBD

Number of US Target Events: Targets Matched and Total

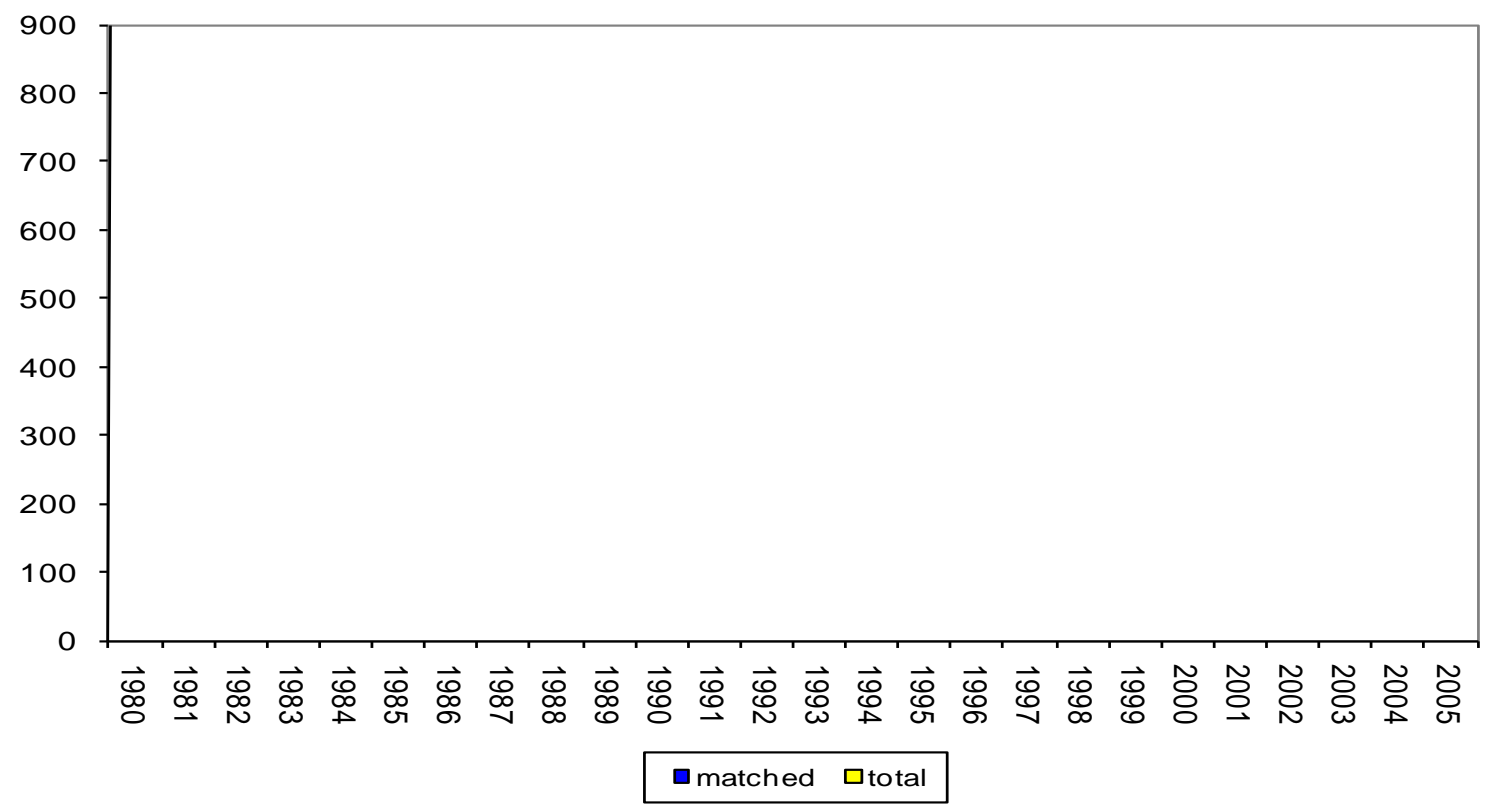

Figure 2: Employment of Matched Targets (Level and Percent of LBD Total)

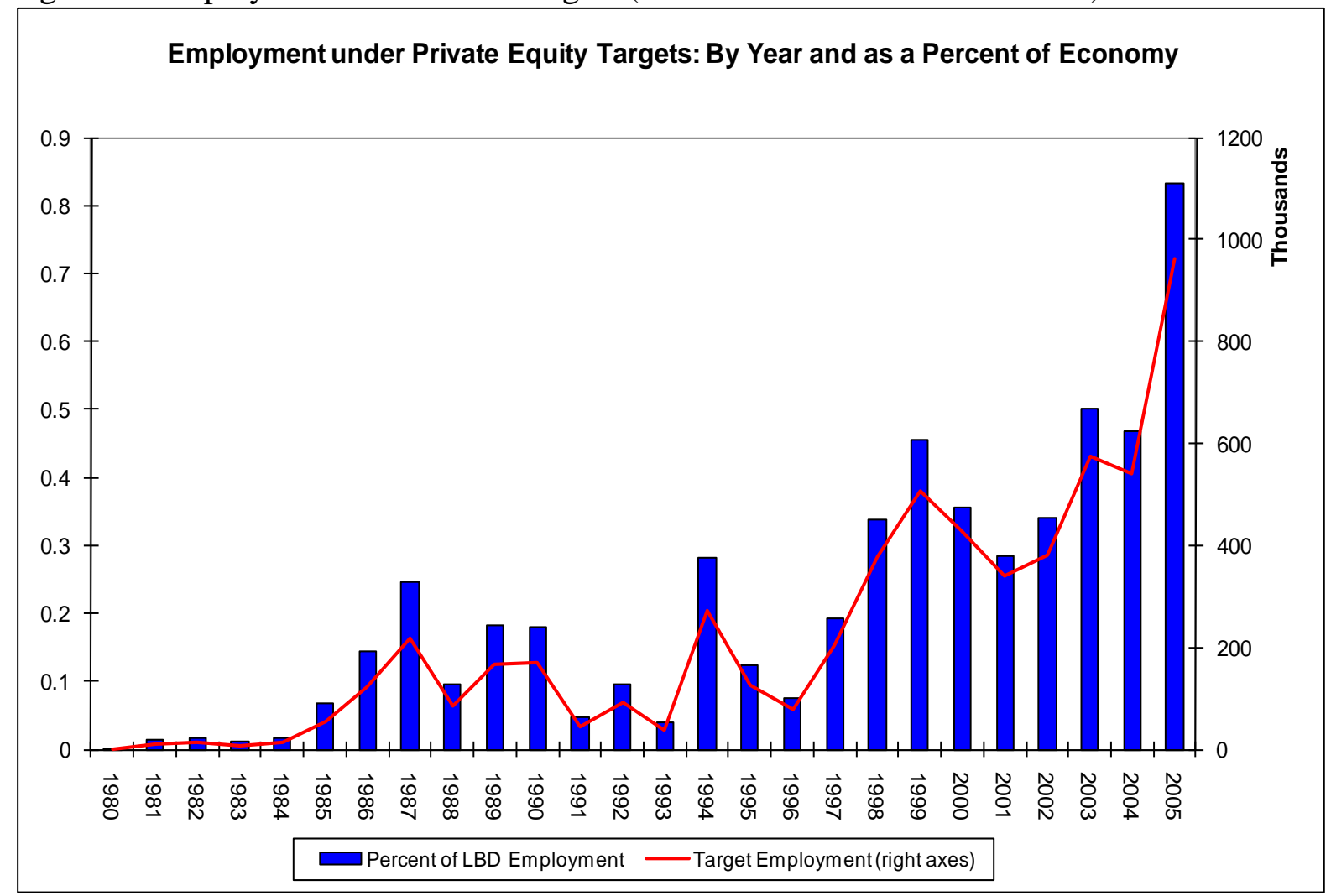


Figure 3A: Industry Distribution of Buyouts and LBD

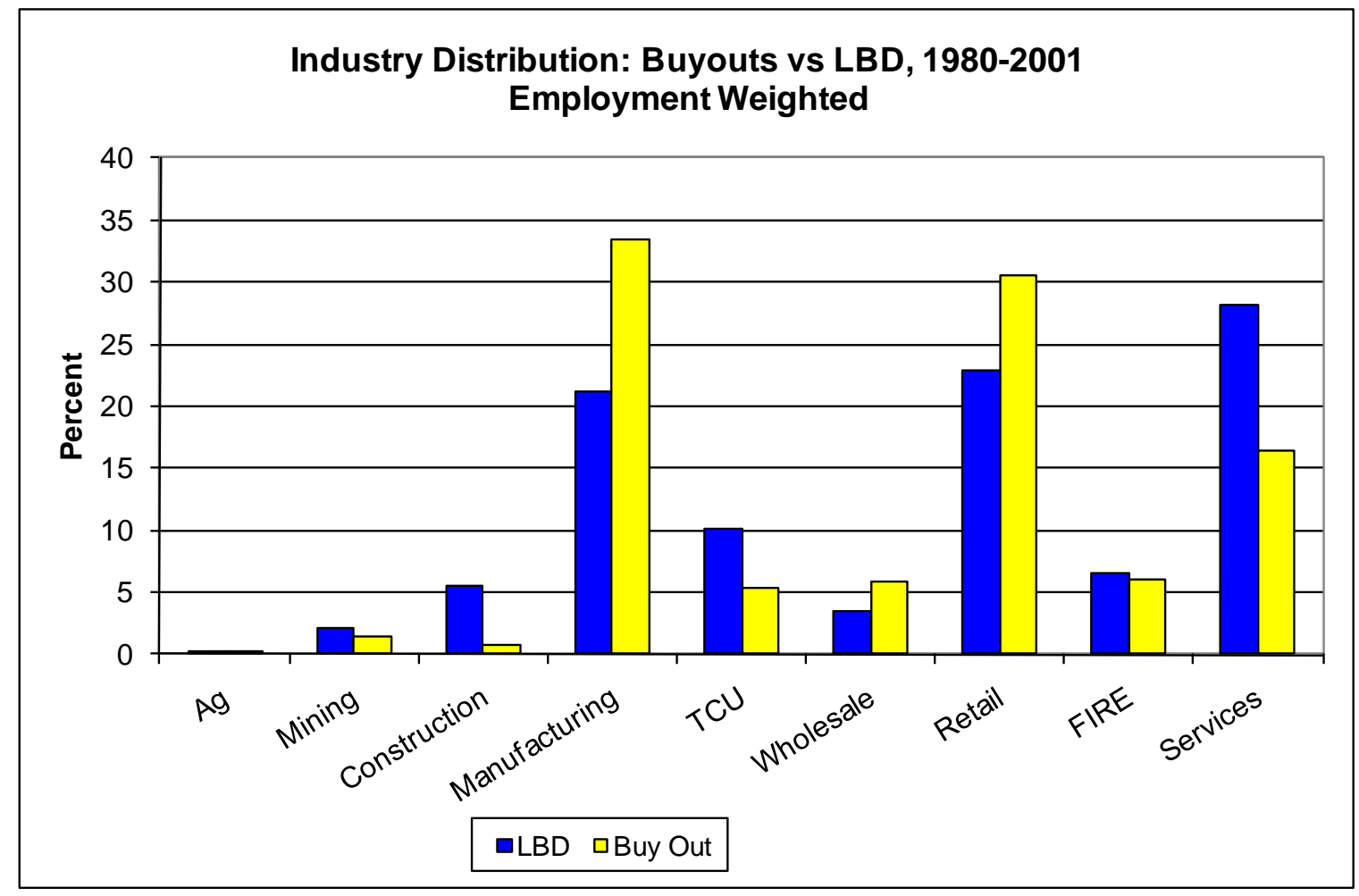

Figure 3B: Industry Distribution of Buyouts and LBD

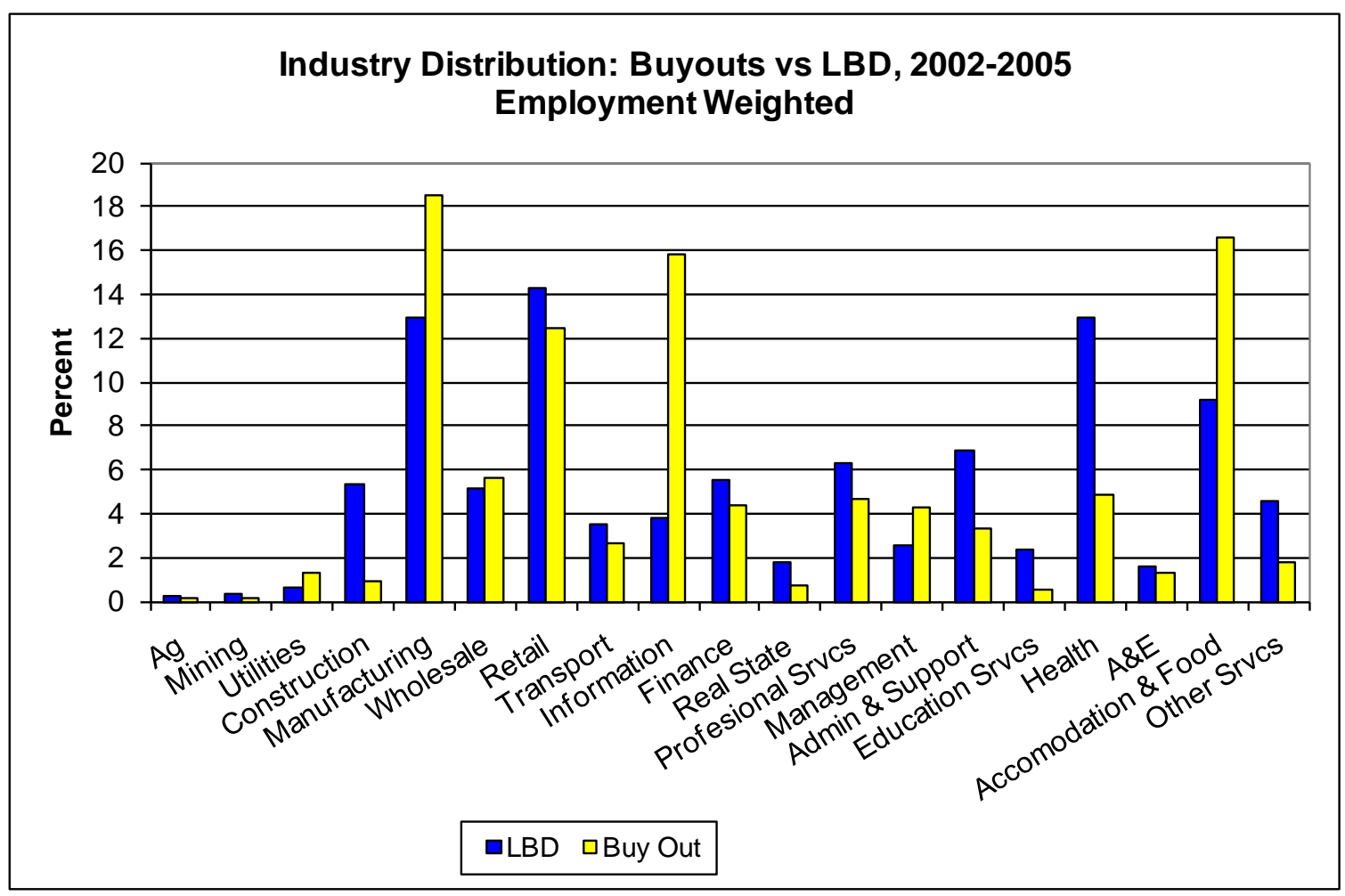


Figure 4: Firm Size and Firm Age Distribution of Matched Targets and LBD
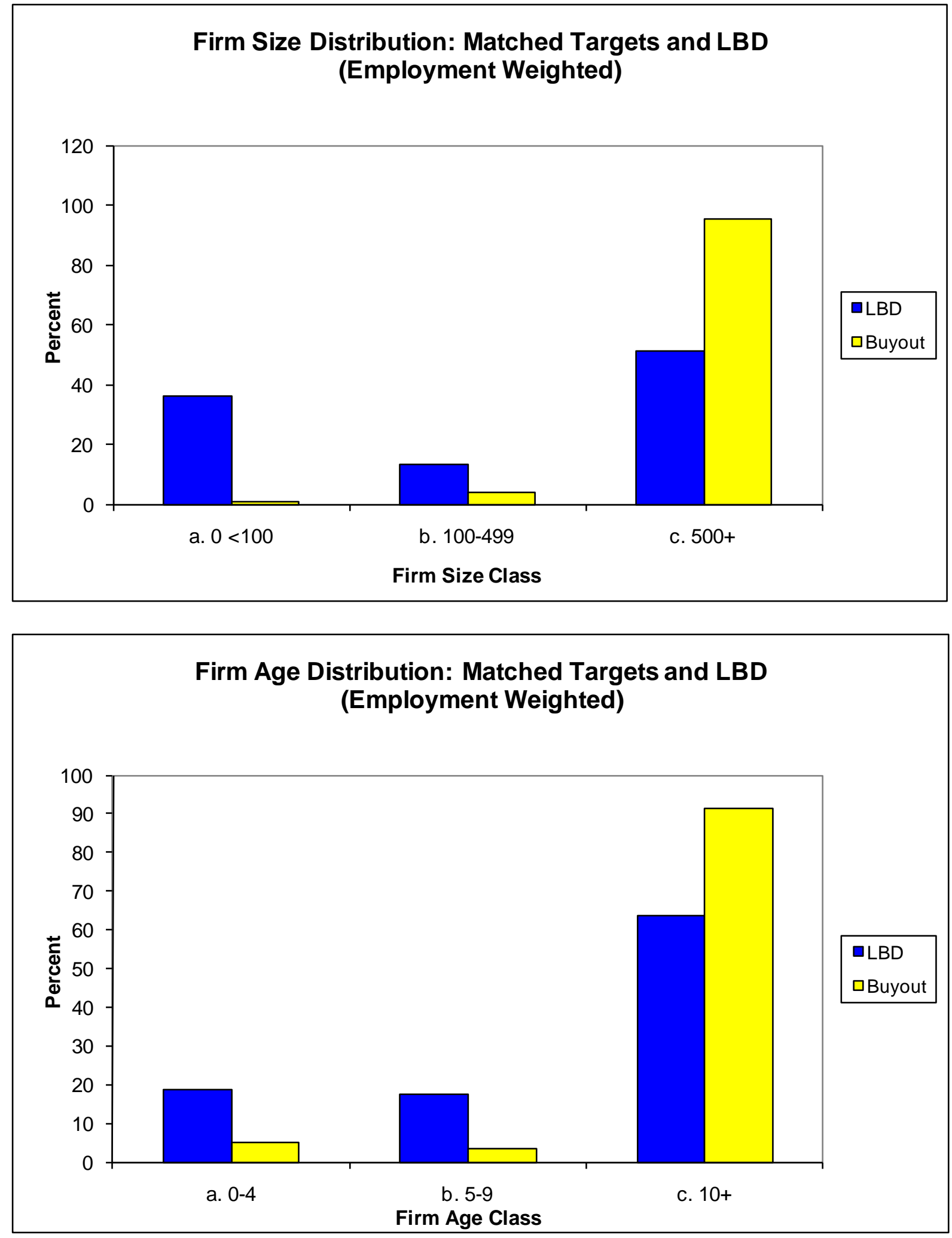
Figure 5A: Employment at Matched Targets and Normalized Controls

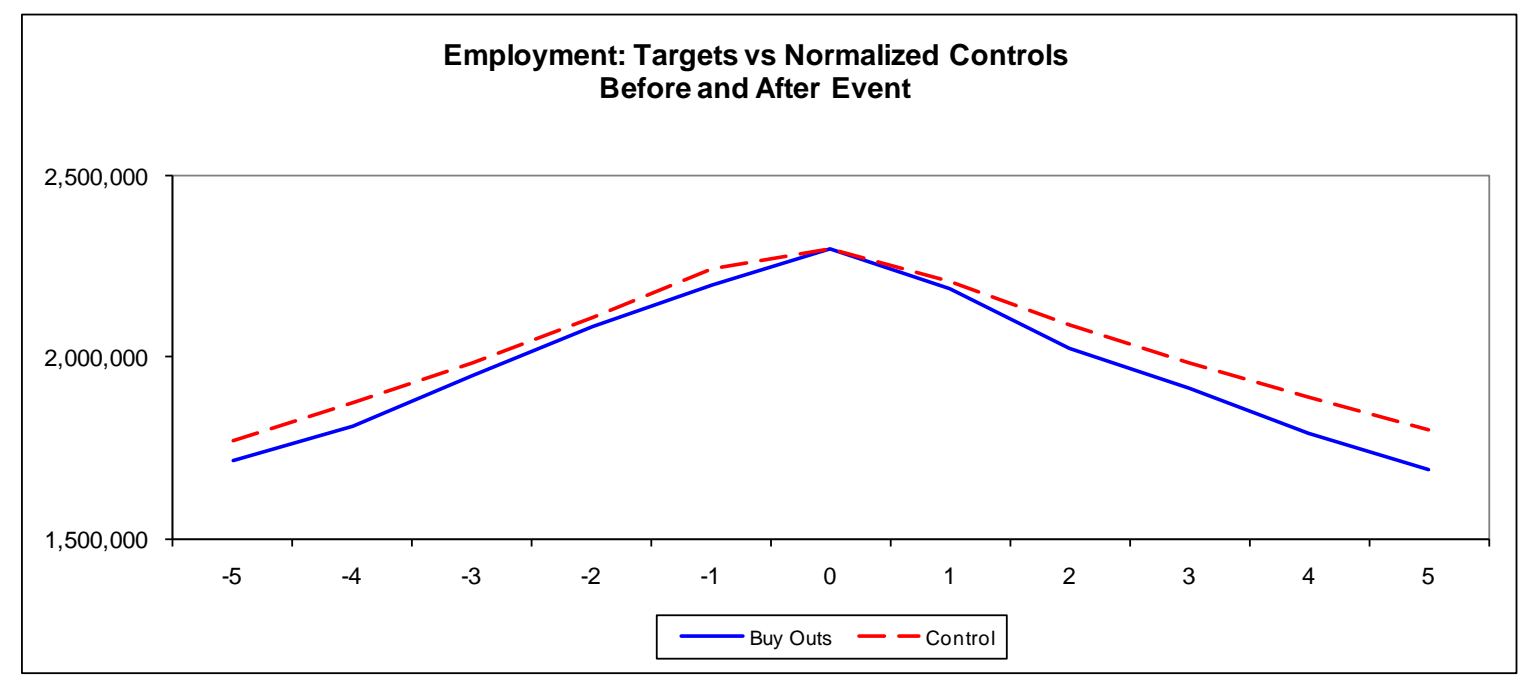

Figure 5B: Comparison of Net Growth Rates

\section{Comparison of Net Growth Rates -- Targets less Controls \\ Before and After Event}

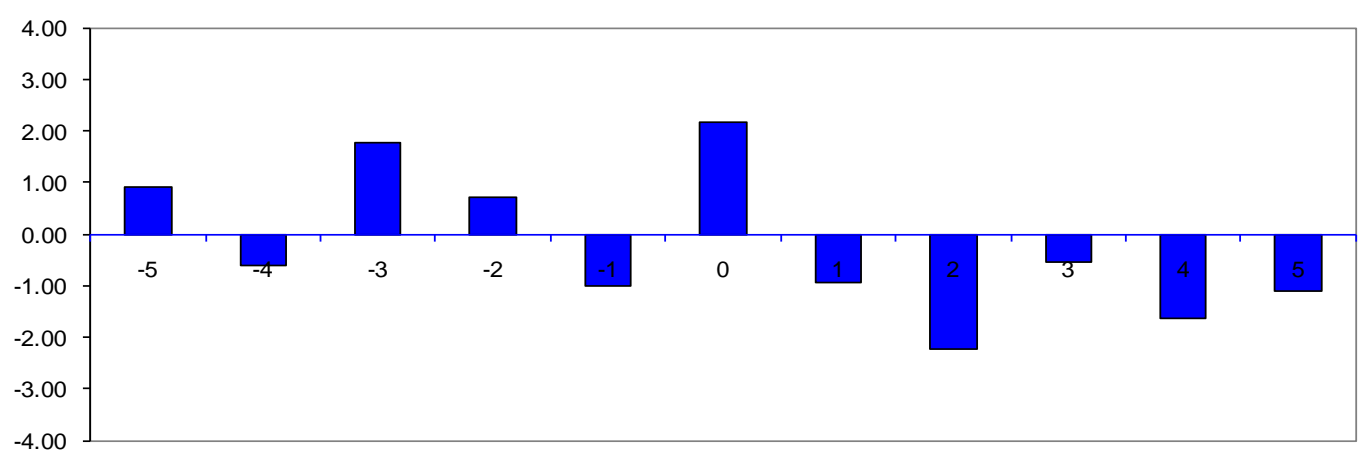


Figure 6A: Job Creation Rates Targets and Controls

\section{Comparison of Job Creation RatesTargets less Controls Before and After Event}

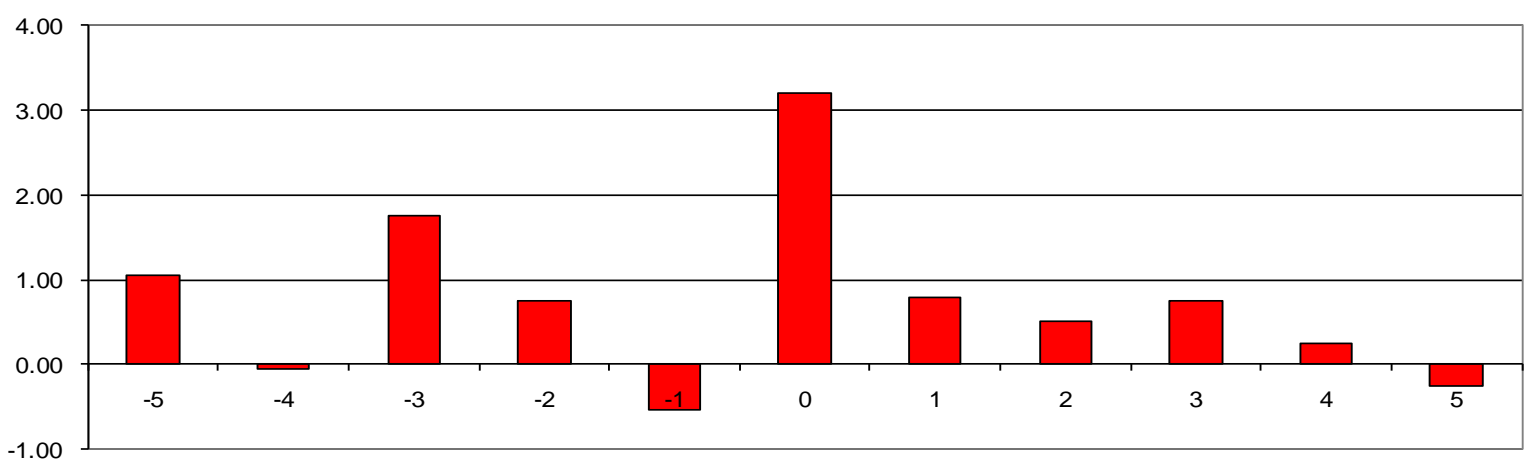

Figure 6B: Job Destruction Rates Targets and Controls

Comparison of Job Destruction Rates: Targets less Controls Before and After Event

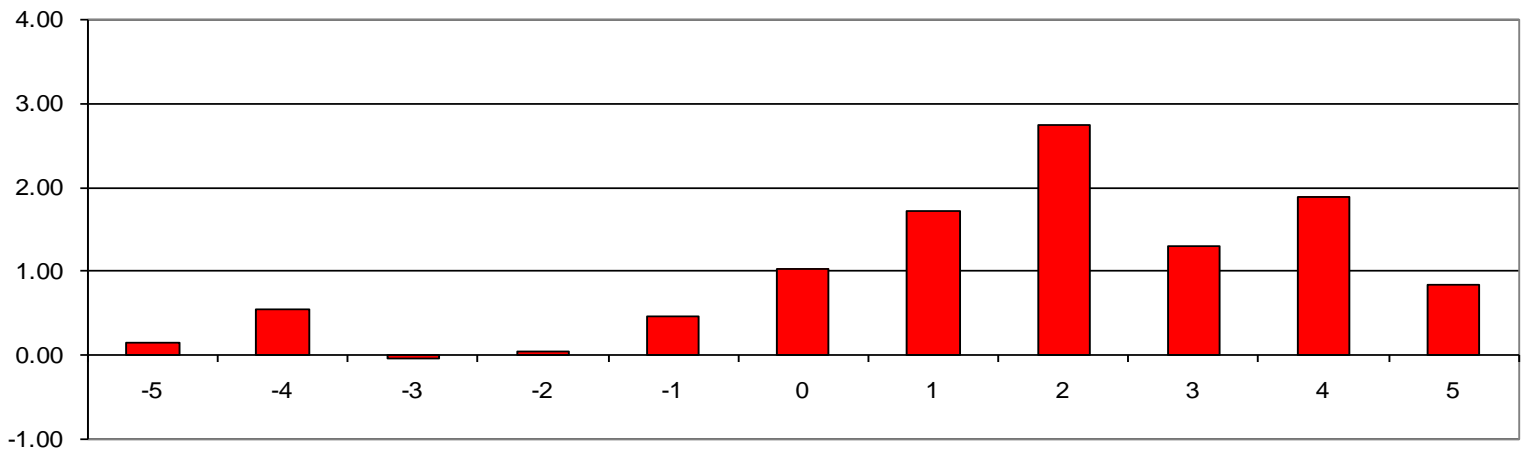

Figure 7: Establishment Exit Rates Targets and Controls

Comparison of Establishment Exit Rates : Targets less Controls After Event

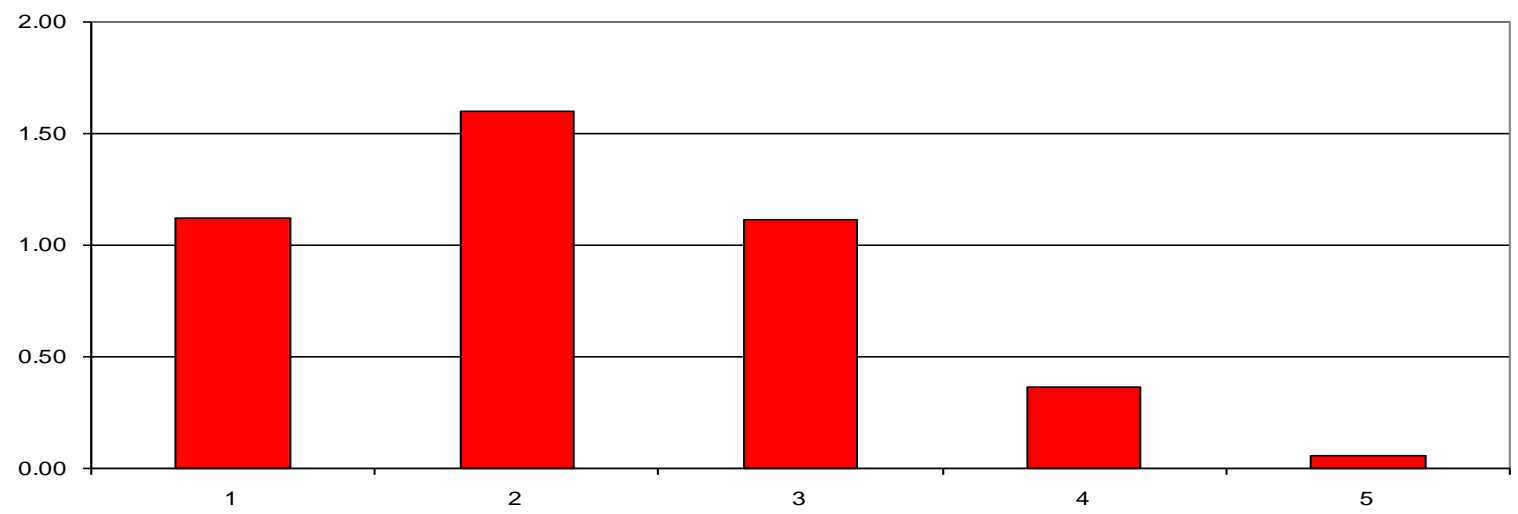


Figure 8: Variation in Impact on Employment Across Broad Sectors

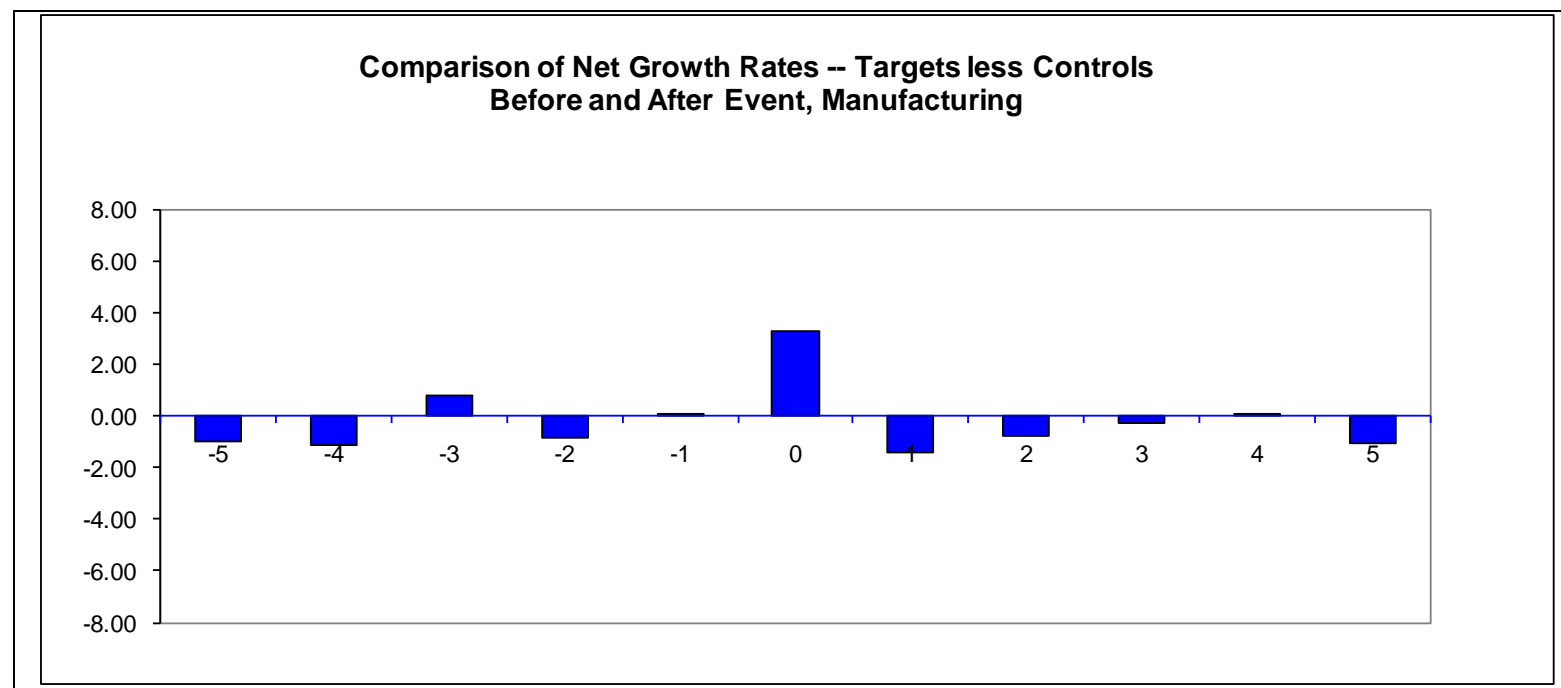

Comparison of Net Growth Rates -- Targets less Controls

Before and After Event, Retail
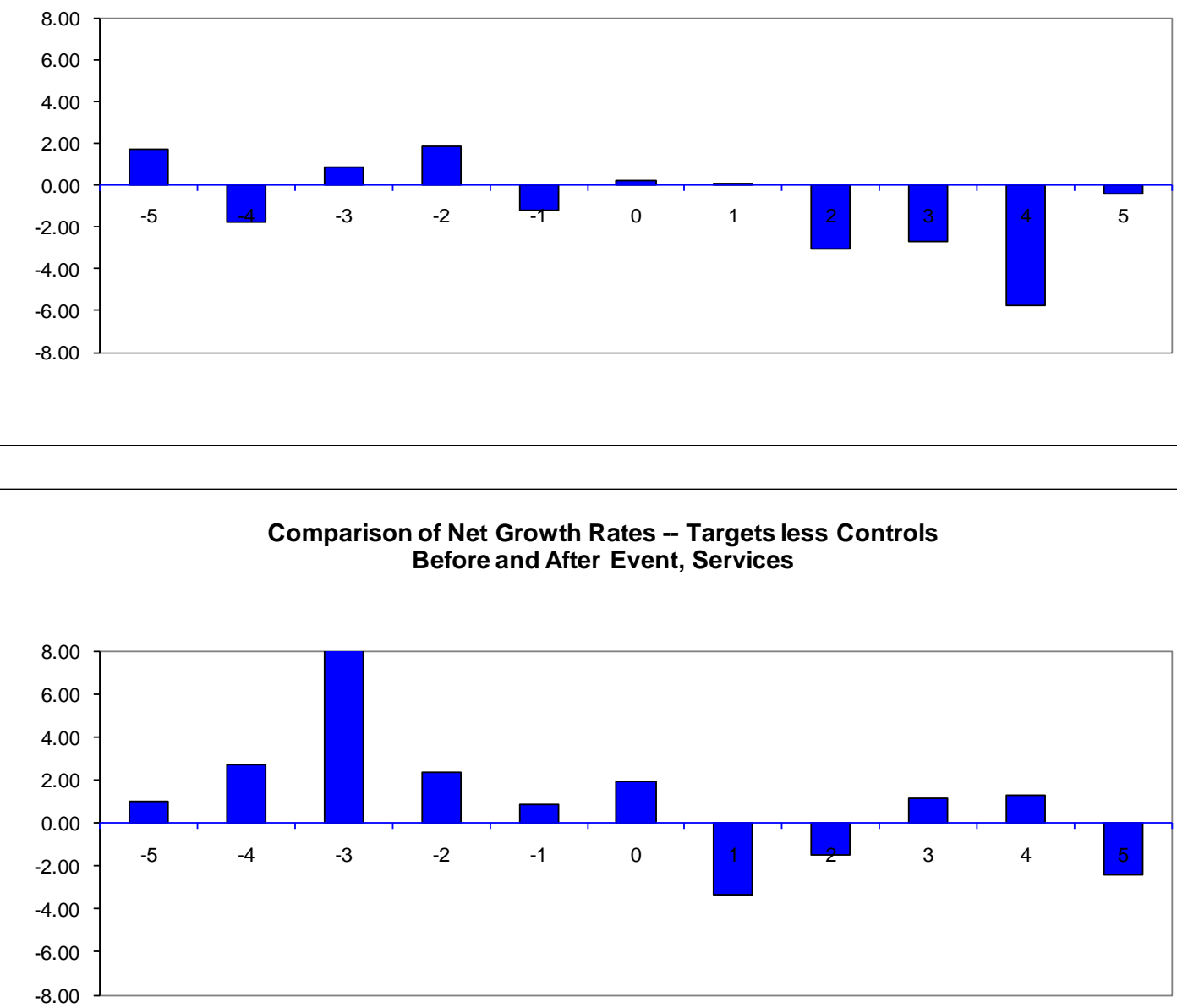
Table 1. Value of Private Equity Targets, Total and Matches by Time Period (\$millions)

\begin{tabular}{|c|c|c|c|}
\hline & 1980-1989 & 1990-1999 & 2000-2005 \\
\hline Matched & 73,209 & 169,271 & 291,824 \\
\hline Total & 122,115 & 211,615 & 420,245 \\
\hline
\end{tabular}

Table 2. Private Equity Transactions in the Analysis Samples

\begin{tabular}{|c|c|c|c|c|}
\hline & $\begin{array}{l}\text { Number of } \\
\text { Transactions } \\
\text { (Target } \\
\text { Firms) }\end{array}$ & $\begin{array}{c}\text { Value of } \\
\text { Transactions } \\
\text { in } 2005 \\
\text { Dollars }\end{array}$ & $\begin{array}{c}\text { Target } \\
\text { Establishments, } \\
\text { Transaction } \\
\text { Year }\end{array}$ & $\begin{array}{c}\text { Target } \\
\text { Employment, } \\
\text { Transaction } \\
\text { Year }\end{array}$ \\
\hline All, 1980-2005 & 3,218 & 573,224 & 151,529 & $5,828,532$ \\
\hline Private to Private & 1,350 & 88,919 & 59,865 & $2,224,530$ \\
\hline Public to Private & 390 & 261,164 & 36,717 & $1,371,129$ \\
\hline Divisional Sales & 918 & 132,330 & 35,259 & $1,359,139$ \\
\hline Secondary Sales & 396 & 72,969 & 13,455 & 637,591 \\
\hline Other & 164 & 17,841 & 6,233 & 236,143 \\
\hline All, 1980-2003 & 2,265 & 431,871 & 103,671 & $4,323,558$ \\
\hline Excluding EIN cases & 1,874 & 377,303 & 79,131 & $3,410,598$ \\
\hline $\begin{array}{l}\text { Two-year continuers, } \\
\text { excluding EIN cases }\end{array}$ & 1,374 & 272,325 & 76,271 & $3,187,171$ \\
\hline Private to Private & 686 & 58,287 & 37,283 & $1,470,447$ \\
\hline Public to Private & 248 & 129,382 & 20,380 & 872,206 \\
\hline Divisional Sales & 206 & 38,874 & 7,922 & 391,705 \\
\hline Secondary Sales & 160 & 35,474 & 7,957 & 353,325 \\
\hline Other & 74 & 10,309 & 2,729 & 99,488 \\
\hline All, 1980-2000 & 1,306 & 315,007 & 54,729 & $2,385,163$ \\
\hline Private to Private & 647 & 60,865 & 24,593 & 901,284 \\
\hline Public to Private & 171 & 162,567 & 18,454 & 854,779 \\
\hline Divisional Sales & 342 & 60,615 & 6,557 & 416,055 \\
\hline Secondary Sales & 107 & 23,010 & 3,885 & 161,557 \\
\hline Other & 39 & 7,951 & 1,240 & 51,488 \\
\hline
\end{tabular}


Table 3. Post-Transaction Employment Growth Rates at Target Establishments Relative to Controls, Transactions from 1980 to 2000

\begin{tabular}{|r|c|c|c|}
\hline & \multirow{2}{*}{$\begin{array}{c}\text { Nonparametric } \\
\text { Comparison }\end{array}$} & \multicolumn{2}{|c|}{ Semi-Parametric Regressions } \\
\cline { 3 - 4 } & $\begin{array}{c}\text { ATE=ATE1 } \\
\text { From Figure 6b }\end{array}$ & & $\begin{array}{c}\text { ATE1 } \\
\text { Heterogeneous }\end{array}$ \\
\hline Buyout Year & 2.17 & 2.08 & 2.28 \\
\hline & & $(0.17)$ & $0.17)$ \\
\hline Buyout Year +1 & -0.93 & -0.72 & -1.15 \\
\hline & & $(0.20)$ & $(0.20)$ \\
\hline+2 & -2.23 & -1.74 & -1.76 \\
\hline & & $(0.20)$ & $0.21)$ \\
\hline & -0.55 & 0.00 & 0.08 \\
\hline+3 & & $(0.21)$ & $(0.21)$ \\
\hline & -1.64 & -1.31 & -1.16 \\
\hline+4 & & $(0.22)$ & $(0.22)$ \\
\hline & -1.09 & -0.95 & -1.23 \\
\hline & & $(0.22)$ & $0.23)$ \\
\hline Cumulative, Years 1 to 5 & -6.44 & -4.72 & -5.22 \\
\hline
\end{tabular}

Notes:

1. Table entries report estimated employment growth rate differences between targets and controls in the buyout year and following years. For example, the entries for "Buyout Year +2 " report the estimated growth rate difference from Year 1 to Year 2 following the buyout. Each reported coefficient is for a different nonparametric comparison or regression. Standard errors are in parentheses. They are computed by the delta method in the "ATE1 Heterogeneous" regression.

2. The nonparametric comparison reflects the patterns displayed in Figure 5b. As explained in the text, this comparison controls for the cross product of 72 two-digit industries, 10 firm size categories, 6 firm age groups, multi-unit status, and transaction year.

3. The semi-parametric regressions control for two-digit industry, firm size categories, firm age categories, multi-unit status and transaction year plus two measures for the prebuyout growth history of the parent firm. The "ATE=ATE1" specification imposes a uniform treatment effect, while the "ATE1 Heterogeneous” specification allows the treatment effect to vary firm size category, firm age category and the pre-buyout growth history measures.

4. The average number of establishment-level observations in each regression or nonparametric comparison is about 4.9 million. The observation count falls with each successive year following the transaction year because of target deaths and deleted observations for the corresponding control establishments. 
Table 4. Buyout Effects on Target Firms Relative to Controls: Employment-Weighted Regression Estimates, Transactions from 1980 to 2003

\begin{tabular}{|c|c|c|c|c|}
\hline \multirow[b]{3}{*}{ Dependent Variable } & \multicolumn{4}{|c|}{ Regression Specification } \\
\hline & \multicolumn{2}{|c|}{$\mathrm{ATE}=\mathrm{ATE} 1$} & \multicolumn{2}{|c|}{$\begin{array}{c}\text { ATE1 } \\
\text { Heterogeneous }\end{array}$} \\
\hline & Buyout Effect & & Buyout Effect & \\
\hline $\begin{array}{r}\text { Firm-level Employment } \\
\text { Growth Rate }\end{array}$ & $\begin{array}{c}-0.88 \\
(0.18) \\
\end{array}$ & 0.07 & $\begin{array}{l}-0.65 \\
(0.16) \\
\end{array}$ & 0.07 \\
\hline By Adjustment Margin & & & & \\
\hline Continuers & $\begin{array}{l}-1.57 \\
(0.12)\end{array}$ & 0.09 & $\begin{array}{l}-1.36 \\
(0.11)\end{array}$ & 0.09 \\
\hline Creation & $\begin{array}{l}-1.33 \\
(0.08)\end{array}$ & 0.20 & $\begin{array}{l}-1.18 \\
(0.07)\end{array}$ & 0.20 \\
\hline Destruction & $\begin{array}{c}0.24 \\
(0.07)\end{array}$ & 0.09 & $\begin{array}{c}0.18 \\
(0.06)\end{array}$ & 0.09 \\
\hline Deaths & $\begin{array}{c}4.12 \\
(0.09)\end{array}$ & 0.06 & $\begin{array}{c}4.13 \\
(0.08)\end{array}$ & 0.06 \\
\hline Births & $\begin{array}{c}1.80 \\
(0.05)\end{array}$ & 0.22 & $\begin{array}{c}1.87 \\
(0.05)\end{array}$ & 0.22 \\
\hline Acquisitions & $\begin{array}{c}5.62 \\
(0.05)\end{array}$ & 0.12 & $\begin{array}{c}5.56 \\
(0.05)\end{array}$ & 0.13 \\
\hline Divestitures & $\begin{array}{l}2.77 \\
(0.05)\end{array}$ & 0.06 & $\begin{array}{c}2.75 \\
(0.04)\end{array}$ & 0.06 \\
\hline
\end{tabular}

Notes:

1. Employment-weighted regressions based on a sample of Target and Control firms with growth rates calculated over two-year horizon from the event year $t$ to $t+2$. Standard errors in parentheses.

2. The semi-parametric regression specifications in Table 4 include fully interacted industry, year, firm age, firm size and multi-unit effects plus additional controls for prebuyout growth history. The "ATE=ATE1" specification imposes a uniform treatment effect, while the "ATE1 Heterogeneous" specification allows the treatment effect to vary by firm size, firm age, and the two measures of pre-buyout growth history.

3. Each regression has $1,985,489$ observations. 
Table 5. Estimated Effects of Buyouts on Excess Reallocation and Total Job Reallocation at the Firm Level, Transactions from 1980 to 2003

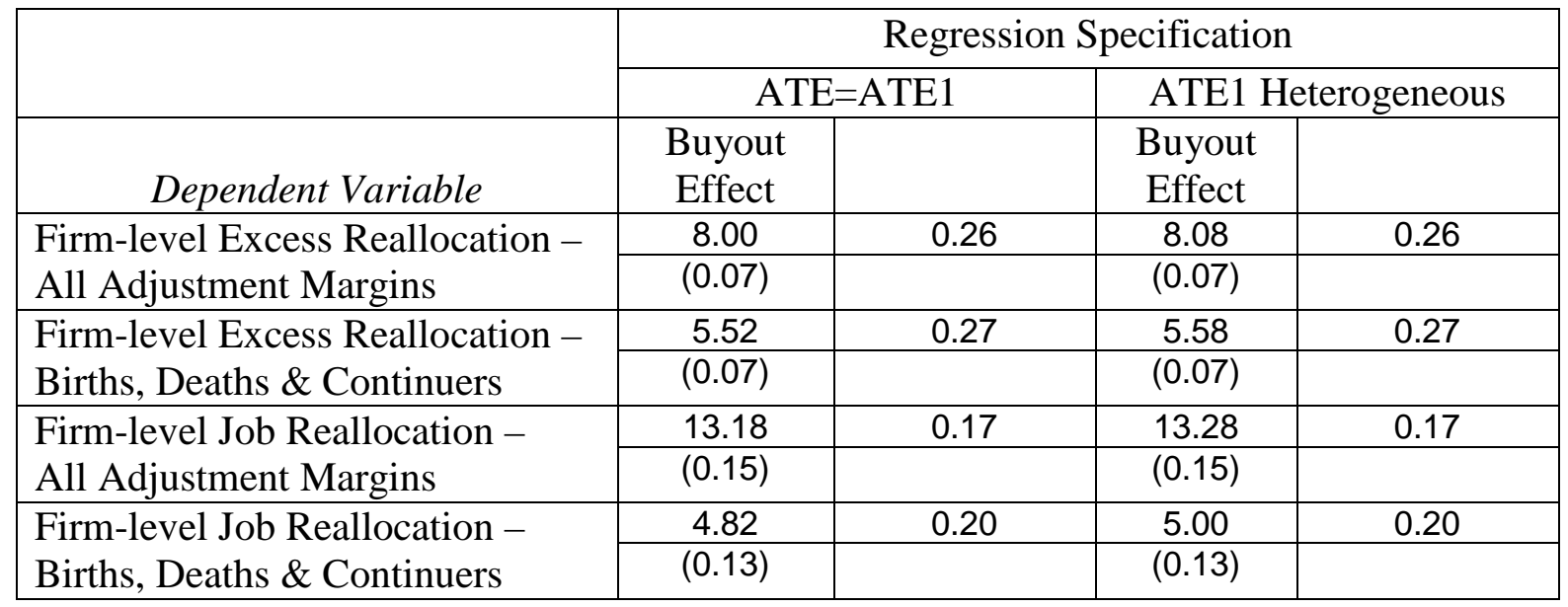

Notes:

1. Employment-weighted regressions based on a sample of Target and Control firms with growth rates calculated over two-year horizon from the event year $t$ to $t+2$. Standard errors in parentheses.

2. The semi-parametric regression specifications in Table 5 include fully interacted industry, year, firm age, firm size and multi-unit effects plus additional controls for prebuyout growth history. The "ATE=ATE1" specification imposes a uniform treatment effect, while the "ATE1 Heterogeneous" specification allows the treatment effect to vary by firm size, firm age, and the two measures of pre-buyout growth history.

3. Each regression has $1,985,489$ observations. 
Table 6. Private Equity and Reallocation, Cumulative Outcomes over Years 1 and 2 Post Transaction for Transactions from 1980 to 2003

A. Organic Changes, Excluding Acquisitions and Divestitures

\begin{tabular}{|r|r|r|r|r|r|}
\hline Rates Expressed as a & Target & Control & & \multicolumn{2}{|c|}{ From Tables 3 and 4 } \\
\cline { 5 - 6 } Percent of Employment & Firms & Firms & Difference & Difference & Standard Error \\
\hline Job Creation & 18.60 & 16.79 & 1.80 & 0.69 & $(0.10)$ \\
\hline Continuers & 5.20 & 5.63 & -0.43 & -1.18 & $(0.07)$ \\
\hline Births & 13.40 & 11.17 & 2.23 & 1.87 & $(0.00)$ \\
\hline Job Destruction & 20.36 & 16.42 & 3.94 & 4.31 & $(0.11)$ \\
\hline Continuers & 6.94 & 6.71 & 0.23 & 0.18 & $(0.06)$ \\
\hline Deaths & 13.42 & 9.70 & 3.71 & 4.13 & $(0.08)$ \\
\hline Employment Growth* & -1.77 & 0.38 & -2.14 & & $(0.13)$ \\
\hline Job Reallocation & 38.96 & 33.21 & 5.75 & 5.00 & \\
\hline Excess Reallocation* & 37.19 & 32.83 & 4.36 & & $(0.13)$ \\
\cline { 5 - 7 } Within-Firm & 20.39 & 15.03 & 5.36 & & \\
\cline { 5 - 7 } Between-Firm & 16.81 & 17.80 & -1.00 & & \\
\hline
\end{tabular}

B. All Adjustment Margins, Including Acquisitions and Divestitures

\begin{tabular}{|c|c|c|c|c|c|}
\hline \multirow{2}{*}{$\begin{array}{l}\text { Rates Expressed as a } \\
\text { Percent of Employment }\end{array}$} & \multirow{2}{*}{$\begin{array}{l}\text { Target } \\
\text { Firms }\end{array}$} & \multirow{2}{*}{$\begin{array}{l}\text { Control } \\
\text { Firms }\end{array}$} & \multirow[b]{2}{*}{ Difference } & \multicolumn{2}{|c|}{ From Tables 3 and 4} \\
\hline & & & & Difference & Standard Error \\
\hline Job Creation & 29.48 & 22.23 & 7.25 & 6.25 & $(0.11)$ \\
\hline Job Destruction & 27.28 & 21.06 & 6.21 & 7.03 & (0.13) \\
\hline Employment Growth & 2.21 & 1.17 & 1.04 & -0.65 & $(0.16)$ \\
\hline Job Reallocation & 56.76 & 43.29 & 13.46 & 13.28 & $(0.15)$ \\
\hline \multirow{3}{*}{$\begin{array}{r}\text { Excess Reallocation* } \\
\text { Within-Firm } \\
\text { Between-Firm* }\end{array}$} & 54.55 & 42.12 & 12.43 & & \\
\hline & 26.16 & 18.27 & 7.89 & 8.08 & $(0.07)$ \\
\hline & 28.39 & 23.85 & 4.54 & & \\
\hline
\end{tabular}

C. Level and Decomposition of Job Reallocation

\begin{tabular}{|r|r|r|}
\hline & Target Firms & Control Firms \\
\hline $\begin{array}{r}\text { Job Reallocation as a Percent of } \\
\text { Transaction-Year Employment }\end{array}$ & 56.76 & 43.29 \\
\hline Components, as Percent of Total & & \\
\hline Net Employment Change, Organic & 3.11 & 0.87 \\
\hline Within-Firm Excess Reallocation, Organic & 35.92 & 34.72 \\
\hline Between-Firm Excess Reallocation, Organic & 29.61 & 41.12 \\
\hline Net Employment Change, A\&D & 7.00 & 1.84 \\
\hline Excess Reallocation, A\&D & 27.47 & 20.59 \\
\hline
\end{tabular}

Notes:

1. An asterisk in Panels A and B denotes values derived from the following identities: First, job creation minus job destruction equals the net employment change. Second, total job reallocation equals organic job reallocation plus job reallocation due to acquisitions and divestitures. Third, job reallocation is the sum of an absolute employment change and excess reallocation. Fourth, excess reallocation is the sum of within-firm (firm-level) and between-firm components. See Section 2.3 in Davis and Haltiwanger (1999) for a development and explicit statement of the first, third and fourth identities.

2. “A\&D” refers to Acquisitions and Divestitures. 
Table 7. Buyout Effects on Target Firms Relative to Controls by Type of Transaction and Adjustment Margin, Transactions from 1980 to 2003

\begin{tabular}{|l|c|c|c|c|c|}
\hline & \multicolumn{5}{|c|}{ Type of Buyout Transaction } \\
\hline \multirow{3}{*}{$\begin{array}{l}\text { Dependent Variable } \\
\text { Net Employment }\end{array}$} & $\begin{array}{c}\text { Public to } \\
\text { Private }\end{array}$ & $\begin{array}{c}\text { Independent } \\
\text { to Private }\end{array}$ & $\begin{array}{c}\text { Divisional } \\
\text { Buyout }\end{array}$ & $\begin{array}{c}\text { Secondary } \\
\text { Buyout }\end{array}$ & Other \\
\cline { 2 - 6 } & -10.36 & 10.51 & -1.47 & 7.15 & -6.45 \\
\hline \multirow{3}{*}{ Adjustment Margin } & $(0.42)$ & $(0.24)$ & $(0.45)$ & $(0.58)$ & $(0.80)$ \\
\hline Continuers & & & & & \\
\hline & 1.40 & 1.44 & -1.42 & 3.11 & -1.84 \\
\hline Divestitures & $(0.25)$ & $(0.16)$ & $(0.31)$ & $(0.38)$ & $(0.56)$ \\
\hline & 6.80 & 0.15 & 5.34 & -0.06 & -1.52 \\
\hline Deaths & $(0.13)$ & $(0.05)$ & $(0.11)$ & $(0.16)$ & $(0.19)$ \\
\hline & 5.95 & 1.50 & 5.97 & 12.14 & 9.28 \\
\hline Births & $(0.19)$ & $(0.12)$ & $(0.23)$ & $(0.30)$ & $(0.44)$ \\
\hline & -3.12 & -0.38 & 3.32 & 17.23 & 1.5 \\
\hline Acquisitions & $(0.14)$ & $(0.07)$ & $(0.13)$ & $(0.19)$ & $(0.25)$ \\
\hline & 3.98 & 10.98 & 7.61 & -1.21 & 1.7 \\
\hline Job Creation All & $(0.25)$ & $(0.06)$ & $(0.12)$ & $(0.16)$ & $(0.21)$ \\
\hline & -0.29 & 9.64 & 9.19 & 20.09 & 1.32 \\
\hline Job Destruction All & $(0.24)$ & $(0.14)$ & $(0.28)$ & $(0.36)$ & $(0.50)$ \\
\hline & 11.06 & -0.88 & 10.34 & 12.04 & 7.84 \\
\hline Excess Reallocation All & $(0.28)$ & $(0.30)$ & $(0.30)$ & $(0.40)$ & $(0.56)$ \\
\hline & 2.14 & 1.67 & 13.65 & 32.25 & 5.29 \\
\hline Number of Observations & $(0.20)$ & $(0.09)$ & $(0.17)$ & $(0.26)$ & $(0.35)$ \\
\hline & 289,228 & $1,269,396$ & 456,135 & 168,508 & 122613 \\
\hline
\end{tabular}

Notes:

1. See notes to Table 4 for the ATE1 Heterogeneous specification. 